\title{
Modeling the primary and secondary productions of the southern Benguela upwelling system: A comparative study through two biogeochemical models
}

\author{
V. Koné, ${ }^{1}$ E. Machu, ${ }^{1}$ P. Penven, ${ }^{2}$ V. Andersen, ${ }^{3}$ V. Garçon, ${ }^{4}$ P. Fréon, ${ }^{1}$ and H. Demarcq ${ }^{1}$ \\ Received 9 December 2004; revised 1 August 2005; accepted 25 October 2005; published 21 December 2005.
}

[1] A three-dimensional primitive equation model, the Regional Ocean Modeling Systems (ROMS), coupled to two biogeochemical configurations (NPZD and $\mathrm{N}_{2} \mathrm{P}_{2} \mathrm{Z}_{2} \mathrm{D}_{2}$ ) was used to study the dynamics of the first trophic levels of the pelagic food web in the southern Benguela upwelling system. The domain extends from the Agulhas Bank bordered by the Agulhas Current to $27^{\circ} \mathrm{S}$ on the west coast of South Africa. The circulation is driven by monthly climatologies of atmospheric forcing fields. The NPZD ecosystem model consists of four state variables: nutrient (nitrate), phytoplankton, zooplankton and detritus. In the $\mathrm{N}_{2} \mathrm{P}_{2} \mathrm{Z}_{2} \mathrm{D}_{2}$ model, ammonium has been added and the three other variables have been divided into small and large organisms or detritus. Both models are able to reproduce the spatio-temporal phytoplankton distribution. Along the west coast, chlorophyll concentrations maxima are associated to surface waters. Westward dominating winds generate the lowest chlorophyll concentrations encountered in winter. The small phytoplankton organisms simulated by the $\mathrm{N}_{2} \mathrm{P}_{2} \mathrm{Z}_{2} \mathrm{D}_{2}$ model are responsible for a weaker chlorophyll inshore/offshore gradient, in closer agreement with observations. Transitions from a regime dominated by new production (high $\mathrm{f}$ ratio) to one dominated by regenerated production (low f ratio) happen to be abrupt, underlying the constant competition between small and large organisms with regard to upwelling induced nutrient inputs. On the Agulhas Bank, the summer enrichment is associated with subsurface maxima, while in winter, mixing by storms results in a homogeneous phytoplankton distribution in the water column. Regenerated production plays an important role in maintaining the total phytoplankton growth. Zooplankton biomass reflects the overall patterns of chlorophyll $a$ concentrations with differences between the west coast and the Agulhas Bank, consistent with data, and its distribution exhibits a clear seasonal contrast. The seasonality of small and large zooplankton in the $\mathrm{N}_{2} \mathrm{P}_{2} \mathrm{Z}_{2} \mathrm{D}_{2}$ model is quite distinct, which allows, from the Agulhas Bank to St. Helena Bay, a food continuum for fish larvae. This was not achieved with the simpler NPZD model, emphasizing the importance of representing the appropriate level of complexity to characterize food availability for higher trophic levels.

Citation: Koné, V., E. Machu, P. Penven, V. Andersen, V. Garçon, P. Fréon, and H. Demarcq (2005), Modeling the primary and secondary productions of the southern Benguela upwelling system: A comparative study through two biogeochemical models, Global Biogeochem. Cycles, 19, GB4021, doi:10.1029/2004GB002427.

\footnotetext{
${ }^{1}$ Centre de Recherche Halieutique Méditerranéenne et Tropicale, Sète, France.

${ }^{2}$ Department of Oceanography, University of Cape Town, Rondebosch, South Africa.

${ }^{3}$ Laboratoire d'Océanographie de Villefranche, Observatoire Océanologique, CNRS-Université Paris VI, Villefranche-sur-mer, France.

${ }^{4}$ Laboratoire d'Etudes en Géophysique et Océanographie Spatiales CNRS, Toulouse, France.

Copyright 2005 by the American Geophysical Union. 0886-6236/05/2004GB002427
}

\section{Introduction}

[2] The Benguela ecosystem is one of four major current systems which exist at the eastern boundaries of the world oceans. The oceanography of the region is in many respects similar to that of the Humboldt Current off Peru and Chile, the California Current and the North African upwelling systems. These eastern boundary currents are characterized by upwelling along the coast of cold nutrient-rich waters. They are important centers of plankton production which support a large biomass of fish such as sardine, anchovy, and many other fish species and also sea birds and marine mammals. 


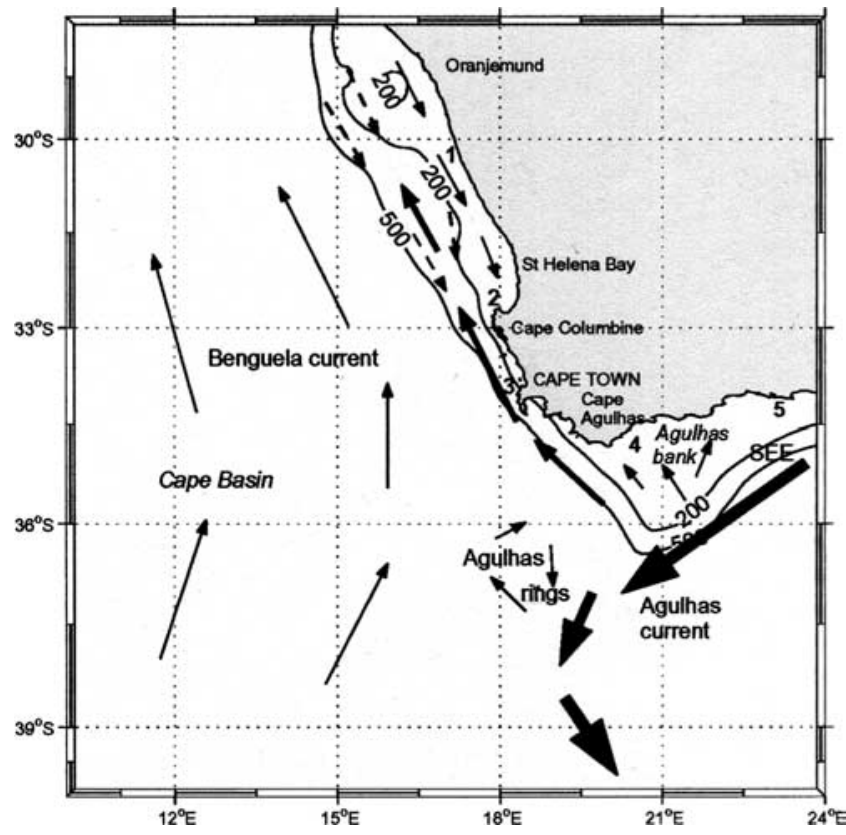

Figure 1. Schematics of the circulation in the southern Benguela upwelling system. Numbers 1 to 5 correspond to the upwelling cells in Namaqualand, Cape Columbine, Cape Peninsula, Cape Agulhas, and Plettenberg, respectively [from Shannon and Nelson, 1996]. Solid line denotes surface currents; dashed line denotes undercurrent; and SEE denotes shear edge eddies.

[3] The coastal upwelling area of the Benguela ecosystem extends from southern Angola $\left(\sim 17^{\circ} \mathrm{S}\right)$ along the west coast of Namibia and South Africa around the southernmost part of the continent. While the area shares many of the generic characteristics of the other boundary currents, it is unique in that it is bordered at both northern and southern boundaries by two warm water systems, the Angola Current and the Agulhas Current, respectively [Shannon and Nelson, 1996; Shillington, 1998]. These equatorward and poleward boundaries are highly dynamic, and their pulsing impacts on the ecosystem as a whole and on its harvested resources. Moreover the intrusions of warm waters in the Benguela system originating in the Indian Ocean may control the rate of thermohaline overturning of the whole Atlantic [Weijer et al., 1999]. From dynamical and ecological considerations, the Benguela upwelling system can be divided into northern and southern regions, the border between them being the Luderitz upwelling cell [Shannon and O'Toole, 1999].

[4] Along the southern Benguela shore, equatorward wind induces offshore advection of surface waters, creating many upwelling cells along the coast (Figure 1) and inducing a highly dispersive environment. In this oceanographic region, sardines and anchovies, the most abundant pelagic fish species, have adapted their reproductive strategies to these environmental constraints. Hydrodynamical properties and the abundance of prey of small pelagic fish influence each step of their life cycle. Sardine and anchovy larvae and juvenile, according to there development stages, feed on phytoplankton, zooplankton, or both. In such a context, we need to understand well the functioning of the first trophic levels of the food chain, which sustain sardines and anchovies development to improve our understanding of the spatio-temporal variability of the pelagic marine resources. The fluctuations of small pelagic stocks and the interactions among the different species originate in nonlinearities linked to the ecosystem structure, in particular to the relationship between physical and biological processes [Huggett et al., 2003; Parada et al., 2003]. Numerical modeling has become a key tool to study the mesoscale dynamics of marine ecosystems due to the inherent difficulty of collecting in situ this information. (a)

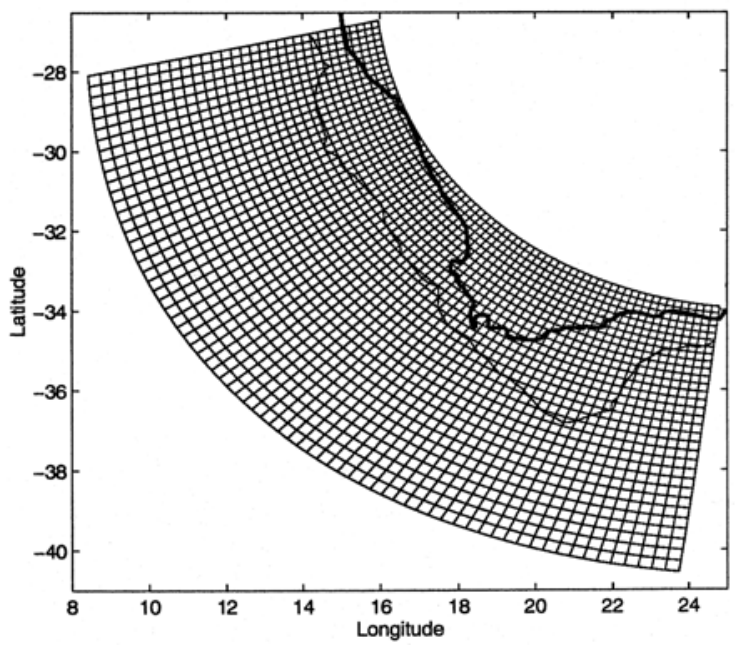

(b)

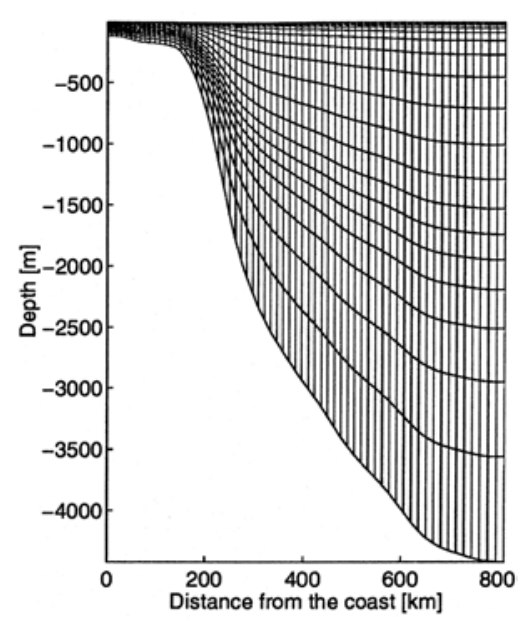

Figure 2. (a) Horizontal grid of the hydrodynamic model. The dark line represents the coastline, and the $500-\mathrm{m}$ isobath is an indicator of the position of the shelf break. (b) Vertical s-coordinate system of the hydrodynamic model following topography. 
Table 1. State Variables of Biogeochemical Models ${ }^{\mathrm{a}}$

\begin{tabular}{ll}
\hline Symbol & \multicolumn{1}{c}{ Variable } \\
\hline$N_{3}$ & NPZD Model \\
$P$ & dissolved inorganic nitrogen (nitrate) \\
$Z$ & phytoplankton \\
$D$ & zooplankton \\
& detritus \\
$N_{4}$ & $N_{2} P_{2} Z_{2} D_{2}$ Model \\
$N O_{3}$ & ammonium \\
$P_{s}$ & nitrate \\
$P_{l}$ & small phytoplankton \\
$Z_{s}$ & large phytoplankton \\
$Z_{l}$ & small zooplankton \\
$D_{s}$ & large zooplankton \\
$D_{l}$ & small detritus \\
\hline
\end{tabular}

${ }^{\mathrm{a}}$ Units for state variables are $\mathrm{mmol} \mathrm{N} \mathrm{m}^{-3}$.

[5] In the southern Benguela, anchovies have distinct spawning patterns. Anchovy display a discrete spawning maximum in summer, while sardines spawn through most of the year, with a slight minimum in winter months and slight maxima in early spring and late summer, bracketing the anchovy spawning. The transport from the spawning area (the Agulhas Bank) to the recruitment area (St. Helena Bay) for anchovies has been studied by Huggett et al. [2003], Mullon et al. [2003] and Parada et al. [2003]. These authors coupled a realistic three-dimensional hydrodynamic model with an individual-based model in order to study the impact of environmental conditions (except food) on the early life stages of pelagic fish eggs and larvae and on the recruitment success.

[6] The goal of the present study is to represent the food availability of pelagic fish larvae during their early life stages. To address this objective, we used coupled physicalbiogeochemical models which we will present in the next section. After a brief description of the observational data set used, we will compare the two biogeochemical models developed in their ability to reproduce the primary and secondary productions in the southern Benguela with a focus on the Agulhas Bank and the west coast. In the last section, we will discuss the relevance of each biogeochemical configuration in the context of food availability for the small pelagic fish (sardines and anchovies).

\section{Models Formulations}

\subsection{Hydrodynamic Model}

[7] The hydrodynamic model is the Regional Ocean Modeling System (ROMS). The reader is referred to Shchepetkin and McWilliams [2005, 2003] for a more complete description of the model. It solves the free surface, primitive equations in an Earth-centered rotating environment, based on the Boussinesq approximation and hydrostatic vertical momentum balance. ROMS is discretized in coastline and terrain-following curvilinear coordinates.

[8] This model has been adapted to the southern Benguela upwelling subregion by Penven [2000] and Penven et al. [2001b] and is briefly described here. In this configuration, the curvilinear grid is pie-shaped to follow roughly the southwest corner of Africa from the Agulhas Bank to
Hondeklip Bay $\left(30^{\circ} \mathrm{S}-17^{\circ} \mathrm{E}\right)$ on the west coast (Figure $2 \mathrm{a}$ ). To facilitate the connection to the open ocean, the northern and eastern open boundaries cut the shelf in its narrowest parts at about $27.5^{\circ} \mathrm{S}$ and $24.5^{\circ} \mathrm{E}$, respectively. Horizontal resolution ranges from $18 \mathrm{~km}$ at the coast to $31 \mathrm{~km}$ offshore, and on the vertical, there are 20 vertical levels. The number of vertical levels is higher near the surface to better resolve upper ocean variability (Figure 2b). The model was forced using the atmospheric forcing fields based on monthly climatologies derived from the Comprehensive Ocean-Atmosphere Data Set (COADS) [Da Silva et al., 1994]. The momentum forcing is given by the longitudinal and latitudinal components of the wind stress.

\subsection{Biogeochemical Models}

[9] Two biogeochemical models have been used to simulate the first trophic levels of the Benguela ecosystem functioning. These models were adapted from the biological model of ROMS developed at UCLA (N. Gruber et al., Simulation of phytoplankton ecosystem dynamics in the California Current System, submitted Deep Sea Research, 2004). The evolution of any biological tracer concentration $C_{i}$ is determined by an advective-diffusive equation,

$$
\frac{\partial C_{i}}{\partial t}=-\nabla \cdot\left(u C_{i}\right)-A_{\rho} \nabla^{2} C_{i}+\frac{\partial}{\partial z}\left(K_{\rho} \frac{\partial C_{i}}{\partial z}\right)+\operatorname{sms}\left(C_{i}\right),
$$

where the first term on the right-hand side accounts for advection, the second accounts for horizontal diffusion (with $A_{\rho}$ representing the horizontal eddy diffusion coefficient), and the third term represents vertical mixing with turbulent diffusion coefficient $K_{\rho}$. The last term is the source-minus-sink term due to biological processes.

\subsubsection{NPZD Version: SC (for Single Compartment)}

[10] The NPZD model contains four state variables (Table 1): dissolved inorganic nitrogen or nitrate $\left(\mathrm{NO}_{3}\right)$, phytoplankton (P), zooplankton (Z), and detritus (D). Interactions between the different compartments are summarized in Figure 3a. All prognostic variables are expressed in nitrogen currency (mmol $\mathrm{N} \mathrm{m}^{-3}$ ). Chlorophyll $a$ in $\mathrm{mg}$ Chla $\mathrm{m}^{-3}$ is derived from phytoplankton concentration using a constant carbon/chlorophyll ratio of 50 [Fasham et al., 1990; Radach and Moll, 1993; Lacroix and Nival, 1998; Tian et al., 2000].

[11] Phytoplankton growth rate is forced by PAR (photosynthetically available radiation), temperature, and dissolved inorganic nitrogen $\left(\mathrm{NO}_{3}\right)$. PAR is calculated at each time step by linearly interpolating monthly climatological values. More details about the radiation conditions in ROMS are given by Marchesiello et al. [2003]. The PAR is calculated using the following formulation:

$$
P A R=P A R_{0} \cdot \exp \left(k_{\text {water }}+k_{\text {chla }} \cdot \theta \cdot r_{C / N, \text { phyto }} \cdot[P] \cdot \Delta z\right) \text {, }
$$

where $P A R_{0}$ is the surface PAR, $k_{\text {water }}$ and $k_{\text {Chla }}$ are attenuation coefficients for pure water and chlorophyll, $\theta$ is the chlorophyll/carbon ratio, $r_{C / N \text {, phyto }}$ is the $\mathrm{C} / \mathrm{N}$ ratio for phytoplankton, $[\mathrm{P}]$ is phytoplankton concentration, and $\Delta z$ is the depth step. Since the chlorophyll concentrations vary spatially, the attenuation coefficients will also do so. The 

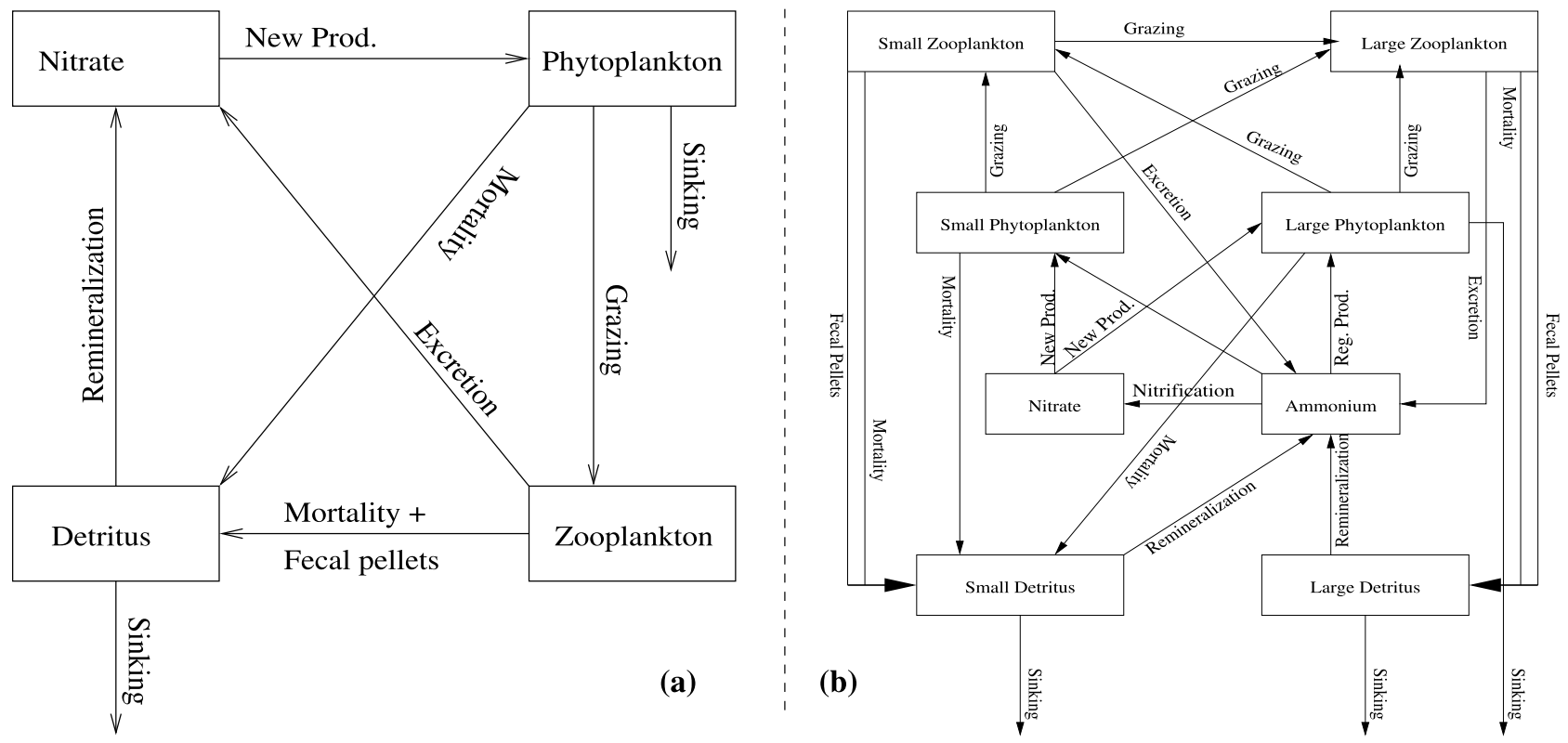

Figure 3. Schematic representations of the fluxes of nitrogen. (a) NPZD model. (b) $\mathrm{N}_{2} \mathrm{P}_{2} \mathrm{Z}_{2} \mathrm{D}_{2}$ model.

phytoplankton growth rate limitation by PAR and temperature is given by

$$
\mu_{p}(P A R, T)=\frac{V_{p} \cdot \alpha \cdot P A R}{\sqrt{V_{p}^{2}+\alpha^{2} \cdot P A R^{2}}} \quad V_{p}=a \cdot b^{T}
$$

where $\mu_{p}(P A R, T)$ is the light- and temperature-limited growth rate $\left(d^{-1}\right), \alpha$ is the initial slope of photosynthesisirradiance (P-I) curve, $V_{p}$ is the light-saturated growth [Oschlies and Garçon, 1999]. Limitation by nitrogen (Nitrate) is given by a Michaelis-Menten function [Parker, 1993],

$$
\mu_{p}(N)=\frac{\left[\mathrm{NO}_{3}\right]}{\mathrm{K}_{\mathrm{NO}_{3}}+\left[\mathrm{NO}_{3}\right]},
$$

where $\mu_{p}(N)$ is the relative nutrient-limited phytoplankton growth rate, $\mathrm{K}_{\mathrm{NO}_{3}}$ is the half-saturation constant for $\mathrm{NO}_{3}$ uptake by phytoplankton. Phytoplankton growth rate is computed as the product of equations (3) and (4),

$$
\mu_{p}=\mu_{p}(P A R, T) \cdot \mu_{p}(N) .
$$

We used the Michaelis-Menten expression [Fasham et al., 1999; Tian et al., 2001] to describe the zooplankton ingestion as a function of phytoplankton concentration. The grazing expression is formulated as follows:

$$
g_{z}=g_{\max } \cdot \frac{[P]}{K_{p}+[P]},
$$

where $g_{\max }$ is the zooplankton maximum grazing rate $\left(d^{-1}\right)$, $[\mathrm{P}]$ is phytoplankton concentration, $K_{p}$ is zooplankton half saturation constant for ingestion. Detritus are a mixture of zooplankton fecal pellets, dead bodies (zooplankton and phytoplankton mortality). Mortality rate is assumed to be constant for both state variables phytoplankton and zooplankton. The remineralization rate of detritus into nitrate $\left(\mathrm{NO}_{3}\right)$ is assumed to be constant. Vertical sinking affects phytoplankton and detritus. The algorithm for the vertical sinking is based on the piecewise parabolic method of Colella and Woodward [1984]. All the model parameters are listed in Table 2. The source and sink terms of the biogeochemical tracers are defined by the following system (equations (7)-(10)), where $L_{v s}$ is the sinking term which includes the sinking velocity $w_{P}$ and $w_{D}$ for phytoplankton and detritus respectively.

$$
\begin{gathered}
\operatorname{sms}\left(N O_{3}\right)=-\mu_{p} \cdot[P]+\mu_{D N} \cdot[D]+\mu_{Z N}[Z] \\
\operatorname{sms}(P)=\mu_{p} \cdot[P]-g_{z} \cdot[Z]-m_{P D} \cdot[P]+L_{v s} \\
\operatorname{sms}(Z)=\beta \cdot g_{z} \cdot[Z]-m_{Z D} \cdot[Z]-\mu_{Z N}[Z] \\
\operatorname{sms}(D)=m_{P D} \cdot[P]+m_{Z D} \cdot[Z]+(1-\beta) \cdot g_{z} \cdot[Z]-\mu_{D N} \cdot[D]+L_{v s} .
\end{gathered}
$$

\subsection{2. $\mathrm{N}_{2} \mathrm{P}_{2} \mathrm{Z}_{2} \mathrm{D}_{2}$ Version: $\mathrm{DC}$ (for Doubled Compartments)}

[12] Within the $\mathrm{N}_{2} \mathrm{P}_{2} \mathrm{Z}_{2} \mathrm{D}_{2}$ model (or DC for doubled compartments), each compartment of the previous NPZD model is split into two state variables (Table 1) according to a size criterion (Figure $3 \mathrm{~b}$ ). The pool of dissolved inorganic nitrogen is represented by nitrate $\left(\mathrm{NO}_{3}\right)$ and ammonium $\left(\mathrm{NH}_{4}\right)$. Phytoplankton organisms are split into small phyto- 
Table 2. NPZD Biogeochemical Model Parameter Values

\begin{tabular}{|c|c|c|c|}
\hline Parameter & Description & Value & Unit \\
\hline $\begin{array}{l}k_{\text {water }} \\
k_{\text {Chla }} \\
\alpha \\
\mathrm{a} \\
\mathrm{b} \\
r_{C / N, p h y t o} \\
\theta \\
K_{N O 3} \\
K_{p} \\
g_{\max } \\
\beta \\
m_{P D} \\
m_{Z D} \\
\mu_{Z N} \\
\mu_{D N} \\
w_{P} \\
w_{D}\end{array}$ & $\begin{array}{l}\text { light attenuation due to seawater } \\
\text { light attenuation by chlorophyll } \\
\text { initial slope of the } P-I \text { curve } \\
\text { phytoplankton maximum growth rate at } 0^{\circ} \mathrm{C} \\
\mathrm{C} / \mathrm{N} \text { ratio for phytoplankton } \\
\text { cellular chlorophyll/C ratio } \\
\text { half-saturation for phytoplankton } \mathrm{NO}_{3} \text { uptake } \\
\text { zooplankton half-saturation constant for ingestion } \\
\text { maximum zooplankton growth rate } \\
\text { zooplankton assimilation coefficient } \\
\text { phytoplankton mortality rate } \\
\text { zooplankton mortality rate } \\
\text { zooplankton specific excretion rate } \\
\text { detrital remineralization to } \mathrm{NO}_{3} \text { rate } \\
\text { sinking velocity for phytoplankton } \\
\text { sinking velocity for Detritus }\end{array}$ & $\begin{array}{l}0.04^{\mathrm{a}, \mathrm{b}, \mathrm{c}, \mathrm{d}, \mathrm{e}} \\
0.024^{\mathrm{f}} \\
0.04^{\mathrm{g}} \\
0.8356^{\mathrm{h}} \\
1.066^{\mathrm{d}, \mathrm{g}} \\
6.625^{\mathrm{i}} \\
0.020^{\mathrm{a}, \mathrm{c}, \mathrm{e}} \\
2.0^{\mathrm{j}, \mathrm{k}} \\
1.0^{\mathrm{f}} \\
0.9^{\mathrm{h}} \\
0.70^{\mathrm{j}, \mathrm{k}} \\
0.03^{\mathrm{c}, \mathrm{d}} \\
0.1^{\mathrm{i}} \\
0.10^{\mathrm{f}} \\
0.05^{\mathrm{d}} \\
0.5^{\mathrm{f}} \\
5.0^{\mathrm{d}}\end{array}$ & $\begin{array}{l}\mathrm{m}^{-1} \\
\left(\mathrm{~m}^{2} \mathrm{mg} \mathrm{Chla}\right)^{-1} \\
\left.\mathrm{mg} \mathrm{C}^{-1} \mathrm{mg} \mathrm{Chla} \mathrm{W} \mathrm{m}{ }^{-2} \mathrm{~d}\right)^{-1} \\
\mathrm{~d}^{-1} \\
\text { n.d. } \\
\text { mol C(mol N})^{-1} \\
\mathrm{mg} \mathrm{Chla}\left(\mathrm{mg} \mathrm{C}^{-1}\right. \\
\text { mmol N m} \\
\text { mmol N m} \\
\mathrm{d}^{-3} \\
\text { n.d. } \\
\mathrm{d}^{-1} \\
\mathrm{~d}^{-1} \\
\mathrm{~d}^{-1} \\
\mathrm{~d}^{-1} \\
\mathrm{~m} \mathrm{~d}^{-1} \\
\mathrm{~m} \mathrm{~d}^{-1}\end{array}$ \\
\hline $\begin{array}{l}{ }^{\mathrm{a}} \text { Fasham } \\
{ }^{\mathrm{b}} \text { Hurtt at } \\
{ }^{\mathrm{c}} \text { Lacroix } \\
{ }^{\mathrm{d}} \text { Oschlie } \\
{ }^{\mathrm{e}} \text { Tian et } \\
{ }^{\mathrm{f}} \text { Olivieri } \\
{ }^{\mathrm{g}} \text { Popova } \\
{ }^{\mathrm{h}} \text { Tuned } \\
{ }^{\mathrm{i}} \text { Redfield } \\
{ }^{\mathrm{j}} \text { Anderse } \\
{ }^{\mathrm{k}} \text { Chifflet } \\
{ }^{\mathrm{l}} \text { Bahamó }\end{array}$ & $\begin{array}{l}\text { [1990]. } \\
\text { strong [1996]. } \\
\text { ival [1998]. } \\
\text { Jarçon [1999]. } \\
\text { o0]. } \\
\text { havez [2000]. } \\
\text { 2002]. } \\
\text { etween the range found in literature. } \\
\text { atio (106/16). } \\
\text { Rassoulzadegan [1991]. } \\
\text { 2001]. } \\
\text { Cruzado [2003]. }\end{array}$ & & \\
\hline
\end{tabular}

plankton (mainly flagellates $\left(P_{S}\right)$ ) and large phytoplankton (mainly diatoms $\left(P_{l}\right)$ ). The two zooplankton compartments now represent microzooplankton as ciliates (small zooplankton $Z_{S}$ ) and mesozooplankton such as copepods (large zooplankton $Z_{l}$ ). To respond to this size fractionation of primary and secondary producers, small and large detritus $\left(D_{s}\right.$ and $\left.D_{l}\right)$ have also been separated. The differentiations flagellates/diatoms and ciliates/copepods are relevant with regards to the a priori knowledge of the main phytoplankton and zooplankton organisms present in the southern Benguela region [Shannon and O'Toole, 1999].

[13] The phytoplankton growth rates are controlled by PAR, nitrogenous nutrients, and temperature. The exponential decrease of light intensity is calculated following equation (1), where $[\mathrm{P}]$ is replaced by the sum of small phytoplankton $\left(P_{S}\right)$ and large phytoplankton $\left(P_{l}\right)$ concentrations. Large or small phytoplankton growth rate limitation by PAR and temperature follows the same formulation as given in equation (3) where the function $\mu_{p}(P A R, T)$ and the parameters $\alpha, \mathrm{a}, \mathrm{b}$ were indexed by $l$ (or $s$ ), respectively. Both phytoplankton growth rates are limited by nitrate $\left(\mathrm{NO}_{3}\right)$ and ammonium $\left(\mathrm{NH}_{4}\right)$, where $\mathrm{NH}_{4}$ is preferred to $\mathrm{NO}_{3}$ for both sizes of phytoplankton [Dugdale and Goering, 1967]. The limitation by nitrogenous nutrients is given by

$$
\begin{aligned}
& \mu_{p_{l}}\left(\mathrm{NH}_{4}\right)=\frac{\left[\mathrm{NH}_{4}\right]}{K_{N H_{4}}^{l}+\left[N H_{4}\right]} \\
& \mu_{p_{l}}\left(\mathrm{NO}_{3}\right)=\frac{\left[N \mathrm{O}_{3}\right]}{K_{N O_{3}}^{l}+\left[N O_{3}\right]} \cdot \frac{K_{N H_{4}}^{l}}{K_{N H_{4}}^{l}+\left[N H_{4}\right]},
\end{aligned}
$$

where $\mu_{p l}\left(\mathrm{NH}_{4}\right)$ and $\mu_{p l}\left(\mathrm{NO}_{3}\right)\left(\mu_{p s}\left(\mathrm{NH}_{4}\right)\right.$ and $\left.\mu_{p s}\left(N \mathrm{O}_{3}\right)\right)$ are the large (small) phytoplankton ammonium and nitrate- limited growth rate, respectively. The large (small) phytoplankton nutrient-limited growth rate $\mu_{p l}(N)\left(\mu_{p s}(N)\right)$ is the sum of both ammonium and nitrate-limited growth rate. $K_{\mathrm{NH}_{4}}^{l}$ and $K_{\mathrm{NO}_{3}}^{l}$ are the half-saturation constants for $\mathrm{NH}_{4}$ and $\mathrm{NO}_{3}$ uptake by large phytoplankton (or $\mathrm{K}_{\mathrm{NH}_{4}}^{\mathrm{S}}$ and $K_{\mathrm{NO}_{3}}^{\mathrm{S}}$ for small phytoplankton), respectively [Parker, 1993]. Small cells are more adapted to oligotrophic conditions than larger ones [Takahashi et al., 1982], so the values of halfsaturation constants are taken to be lower for the small phytoplankton (Table 3). The phytoplankton growth rate is computed as the product of all the limitation terms.

[14] The large zooplankton (copepods) consumes small and large phytoplankton and small zooplankton with different filtration efficiency. The copepods filter the diatoms with more efficiency than flagellates [Andersen and Rassoulzadegan, 1991; Chifflet et al., 2001]. The small zooplankton feeds on small and large phytoplankton with also different filtration efficiency. The specific feeding rate of a predator $j$ on food type $i$ is calculated as

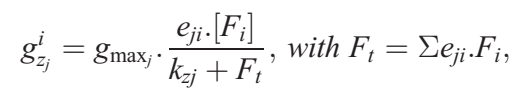

where $g_{\text {max }_{j}}$ is the maximum grazing rate of the predator $j(j$ represents small or large zooplankton), $e_{j i}$ is the preference (or capture efficiency) of predator $j$ to prey $i,\left[F_{i}\right]$ is prey $i$ concentration, $k_{z j}$ is the half-saturation constant for predator $j$ ingestion, and $F_{t}$ is the total food available for predator $j$ [Fasham et al., 1999; Tian et al., 2000].

[15] Small detritus are a mixture of small zooplankton fecal pellets, dead bodies of small zooplankton, and small and large phytoplankton, whereas large detritus is mainly 
Table 3. $N_{2} P_{2} Z_{2} D_{2}$ Biogeochemical Model Parameter Values

\begin{tabular}{|c|c|c|c|}
\hline Parameter & Description & Value & Unit \\
\hline$k_{\text {water }}$ & light attenuation due to sea water & $0.04^{\mathrm{a}, \mathrm{b}, \mathrm{c}, \mathrm{d}, \mathrm{e}}$ & $\mathrm{m}^{-1}$ \\
\hline$k_{\text {Chla }}$ & light attenuation by chlorophyll & $0.024^{\mathrm{f}}$ & $\left(\mathrm{m}^{2} \mathrm{mg} \mathrm{Chla}\right)^{-1}$ \\
\hline$\alpha_{s}$ & $P_{s}$ initial slope of the $P-I$ curve & $0.025^{\mathrm{d}}$ & mg C(mg Chla W m $\left.{ }^{-2} \mathrm{~d}\right)^{-1}$ \\
\hline$\alpha_{l}$ & $P_{l}$ initial slope of the $P-I$ curve & $0.04^{\mathrm{g}}$ & mg C(mg Chla W m $\left.{ }^{-2}\right)^{-1}$ \\
\hline$a_{s}$ & $P_{s}$ maximum growth rate at $0 \mathrm{C}$ & $0.557^{\mathrm{h}}$ & $d^{-1}$ \\
\hline$a_{l}$ & $P_{l}$ maximum growth rate at $0 \mathrm{C}$ & $0.8356^{\mathrm{h}}$ & $d^{-1}$ \\
\hline $\mathrm{b}$ & & $1.066^{\mathrm{d}, \mathrm{g}}$ & n.d. \\
\hline$r_{C / N, p h y t o}$ & $\mathrm{C} / \mathrm{N}$ ratio for phytoplankton & $6.625^{\mathrm{i}}$ & $\operatorname{mol~C}(\mathrm{mol} \mathrm{N})^{-1}$ \\
\hline$\theta$ & cellular chlorophyll/C ratio & $0.020^{\mathrm{a}, \mathrm{c}, \mathrm{e}}$ & $\operatorname{mg~Chla~}(\mathrm{mg} \mathrm{C})^{-1}$ \\
\hline$K_{\mathrm{NO}_{3}}^{S}$ & $P_{S}$ half-saturation constant for $\mathrm{NO}_{3}$ uptake & $1.0^{\mathrm{j}}$ & $\mathrm{mmol} \mathrm{N} \mathrm{m}^{-3}$ \\
\hline $\mathrm{K}_{\mathrm{NO}_{3}}^{l}$ & $P_{l}$ half-saturation constant for $\mathrm{NO}_{3}$ uptake & $2.0^{\mathrm{j}}$ & $\mathrm{mmol} \mathrm{N} \mathrm{m}^{-3}$ \\
\hline $\mathrm{K}_{\mathrm{NH}_{4}}^{S}$ & $P_{s}$ half-saturation constant for $\mathrm{NH}_{4}$ uptake & $0.5^{\mathrm{e}, \mathrm{f}}$ & $\mathrm{mmol} \mathrm{N} \mathrm{m}^{-3}$ \\
\hline$K_{\mathrm{NH}_{4}}^{l}$ & $P_{l}$ half-saturation constant for $\mathrm{NH}_{4}$ uptake & $0.7^{\mathrm{k}, \mathrm{c}}$ & $\mathrm{mmol} \mathrm{N} \mathrm{m}^{-3}$ \\
\hline$K_{z l}$ & large zooplankton half-saturation constant for ingestion & $2.0^{\mathrm{h}}$ & $\mathrm{mmol} \mathrm{N} \mathrm{m}^{-3}$ \\
\hline$K_{z s}$ & small zooplankton half-saturation constant for ingestion & $1.0^{\mathrm{h}}$ & $\mathrm{mmol} \mathrm{N} \mathrm{m}^{-3}$ \\
\hline$g_{\max _{l}}$ & large zooplankton maximum growth rate & $0.96^{\mathrm{c}}$ & $\mathrm{d}^{-1}$ \\
\hline$g_{\max _{s}}$ & small zooplankton maximum growth rate & $1.2^{\mathrm{j}, \mathrm{k}}$ & $d^{-1}$ \\
\hline & large zooplankton assimilation coefficient & $0.70^{\mathrm{a}, \mathrm{c}}$ & n.d. \\
\hline$\beta_{s}$ & small zooplankton assimilation coefficient & $0.75^{\mathrm{d}, \mathrm{f}}$ & n.d. \\
\hline$e_{z_{s} p_{s}}$ & capture efficiency of $P_{s}$ by $Z_{s}$ & $1.0^{\mathrm{j}}$ & n.d. \\
\hline$e_{z_{s}} p_{l}$ & capture efficiency of $P_{l}$ by $Z_{s}$ & $0.4^{\mathrm{h}}$ & n.d. \\
\hline$e_{z_{l} p_{s}}$ & capture efficiency of $P_{s}$ by $Z_{l}$ & $0.5^{\mathrm{c}}$ & n.d. \\
\hline$e_{z_{l} p_{l}}^{-l P s}$ & capture efficiency of $P_{l}$ by $Z_{l}$ & $1.0^{\mathrm{j}}$ & n.d. \\
\hline$e_{z_{l} z_{s}}$ & capture efficiency of $Z_{s}$ by $Z_{l}$ & $0.4^{\mathrm{h}}$ & n.d. \\
\hline$m_{P_{s D}}$ & small phytoplankton mortality to detritus rate & $0.027^{\mathrm{h}}$ & $d^{-1}$ \\
\hline$m_{P_{I D}}$ & large phytoplankton mortality rate & $0.03^{\mathrm{c}, \mathrm{d}}$ & $\mathrm{d}^{-1}$ \\
\hline$m_{Z_{s D}}$ & small zooplankton mortality rate & $0.025^{\mathrm{h}}$ & $\mathrm{d}^{-1}$ \\
\hline$m_{Z_{I D}}$ & large zooplankton mortality rate & $0.05^{\mathrm{f}}$ & $\mathrm{d}^{-1}$ \\
\hline$\mu_{Z_{s A}}$ & small zooplankton specific excretion rate & $0.10^{\mathrm{f}}$ & $d^{-1}$ \\
\hline$\mu_{Z_{l A}}$ & large zooplankton specific excretion rate & $0.05^{\mathrm{h}}$ & $\mathrm{d}^{-1}$ \\
\hline$\mu_{D_{s A}}$ & small detrital breakdown to $\mathrm{NH}_{4}$ rate & $0.1^{1, \mathrm{~m}}$ & $\mathrm{~d}^{-1}$ \\
\hline$\mu_{D_{L A}}$ & large detrital breakdown to $\mathrm{NH}_{4}$ rate & $0.05^{\mathrm{d}}$ & $d^{-1}$ \\
\hline$\mu_{A N}$ & nitrification rate of $\mathrm{NH}_{4}$ to $\mathrm{NO}_{3}$ & $0.05^{\mathrm{h}}$ & $d^{-1}$ \\
\hline$w_{P_{l}}$ & sinking velocity for large phytoplankton & $0.5^{\mathrm{d}, \mathrm{f}, \mathrm{j}}$ & $\mathrm{m} \mathrm{d}^{-1}$ \\
\hline$w_{D_{s}}$ & sinking velocity for small detritus & $1.0^{\mathrm{h}}$ & $\mathrm{m} \mathrm{d}^{-1}$ \\
\hline$w_{D_{s}}$ & sinking velocity for large detritus & $5.0^{\mathrm{d}}$ & $\mathrm{m} \mathrm{d}^{-1}$ \\
\hline
\end{tabular}

${ }^{\mathrm{a}}$ Fasham et al. [1990].

${ }^{\mathrm{b}}$ Hurtt and Armstrong [1996].

${ }^{\mathrm{c}}$ Lacroix and Nival [1998].

${ }^{\mathrm{d}}$ Oschlies and Garçon [1999].

${ }^{\mathrm{e}}$ Tian et al. [2000].

${ }^{\mathrm{f}}$ Olivieri and Chavez [2000].

${ }^{\mathrm{g}}$ Popova et al. [2002].

${ }^{\mathrm{h}}$ Tuned value between the range found in literature.

${ }^{\mathrm{i}}$ Redfield $\mathrm{C} / \mathrm{N}$ ratio $(106 / 16)$.

${ }^{\mathrm{j}}$ Chifflet et al. [2001].

${ }^{\mathrm{k}}$ Bahamón and Cruzado [2003].

${ }^{1}$ Doney et al. [1996].

${ }^{\mathrm{m}}$ Liu et al. [2002].

composed of large zooplankton fecal pellets and dead bodies. The remineralization rates for both small and large detritus are taken as constant. $\mathrm{NH}_{4}$ is transformed into $\mathrm{NO}_{3}$ with a constant nitrification rate. Ammonium $\left(\mathrm{NH}_{4}\right)$ pool is also supplied by zooplankton excretion, with a constant excretion rate. Source-minus-sink terms of biogeochemical state variable evolutions are given in Appendix A. Corresponding parameters are also summarized in Table 3.

\subsection{Initial and Boundary Conditions and Numerical Implementation}

[16] Coastal modeling requires well behaved, long term solutions for configurations with open boundaries on up to three sides. A numerical boundary scheme should allow the inner solution to radiate through the boundary without reflection and information from the surrounding ocean to come into the model. The active open boundary scheme implemented in ROMS hydrodynamic model estimates the two-dimensional horizontal phase velocities in the vicinity of the boundary [Marchesiello et al., 2001]. The velocities phase for each variable is given by Raymond and Kuo's [1984] formulation. The interior and open ocean propagations at the open boundaries are fully described by Penven [2000]. The hydrodynamical model includes relaxation times $\tau$ chosen empirically to avoid long-term drift and overspecification: $\tau_{\text {out }}=360$ days for all the variables (for the outflow boundary), $\tau_{i n}=10$ days for the velocities (for the inflow boundary), and $\tau_{i n}=3$ days for the tracers (for the inflow boundary). A simple nongradient scheme is applied for the boundary condition of the free surface elevation, since the boundary value of the free surface elevation does not affect the inner solution on a C-grid. 
Table 4. Initial Values for State Variables ${ }^{\mathrm{a}}$

\begin{tabular}{lll}
\hline \multicolumn{1}{c}{ Component } & Value \\
\hline & NPZD Model & \\
Phytoplankton & & 0.1 \\
Zooplankton & & 0.06 \\
Detritus & 0.02 \\
& $N_{2} P_{2} Z_{2} D_{2}$ Model & \\
$\mathrm{NH}_{4}$ & & 0.1 \\
Small phytoplankton & & 0.04 \\
Large phytoplankton & 0.06 \\
Small zooplankton & 0.04 \\
Large zooplankton & & 0.04 \\
Small detritus & 0.02 \\
Large detritus & & 0.02 \\
\hline
\end{tabular}

${ }^{a}$ Units for state variables are $\mathrm{mmol} \mathrm{N} \mathrm{m}^{-3}$.

[17] An important particularity of the regional model of the South African Coast is the highly energetic Agulhas Current that is flowing into the domain via the eastern boundary. The presence of this meandering current creates instabilities in the model after a year or two of simulation. A specific open boundary scheme (originally proposed by Flather [1976]) has been implemented into the code for the barotropic component of the velocities (perpendicular to the boundaries), to obtain a long-term stable solution. Information is constantly provided by the boundary, that could overdetermine the inner solution [Penven, 2000].

[18] The initial and boundary conditions for the hydrodynamical model have been derived from the outputs of the Geophysical Fluid Dynamics Laboratory (GFDL) Modular Ocean Model (MOM), version 2, run in a climatology configuration (see section 2.1). The seasonal time-averaged outputs of the AGAPE basin scale ocean model [Biastoch and $\operatorname{Krau} \beta, 1999]$ forced the model three lateral boundaries and connect them to the surroundings. This seasonal model outputs give an annual cyclic information for the following variables: both components $(\mathrm{u}, \mathrm{v})$ of the current, the average current $(\bar{u}, \bar{v})$, temperature $(\mathrm{T})$, salinity $(\mathrm{S})$ and the sea surface elevation $(\zeta)$. To avoid discontinuities in the climatology and forcing fields, the model linearly interpolates in time the data to obtain a field at each model time step.

[19] For both SC and DC models, the initial and boundary conditions of nitrate $\left(\mathrm{NO}_{3}\right)$ distribution are given by an analytical profile derived from Conkright et al. [1994]. Initial conditions for all other state variables are assumed to be constant, and listed in Table 4.

[20] We allowed a spin-up time of 3 years of the coupled physical/biogeochemical model to obtain a stable annual cycle. For more details about the biogeochemical model's stability and equilibria, see auxiliary material figure fs $01 .{ }^{1}$ In the results section, we therefore present model outputs of the fourth year of simulation.

\section{Observational Data}

[21] The biogeochemical models were validated by comparing model outputs with remotely sensed chlorophyll $a$ concentrations as well as in situ phytoplankton and zoo-

\footnotetext{
${ }^{1}$ Auxiliary material is available at $\mathrm{ftp} / / / \mathrm{ftp}$.agu.org/apend/gb/
} 2004GB002427. plankton observations. Phytoplankton pigment concentrations used in this study were obtained from SeaWiFS (Seaviewing Wide Field-of-View Sensor). Surface chlorophyll $a$ concentrations are derived from the global area coverage (GAC) products acquired by SeaWiFS offering a resolution of $4.5 \mathrm{~km}$. Data are issued from the third reprocessing using the standard OC4v4 algorithm validated in August 2002. A daily spatial composite of the standard chlorophyll $a$ was performed by merging data from different orbits (two over the South Benguela region) and a monthly climatology was used [Demarcq et al., 2003], as a comparison basis with the model outputs.

[22] The zooplankton data are based on regular surveys performed since 1988 until 2000. Two surveys are conducted each year, one in November to estimate the prerecruitment success and another one in June in order to estimate the recruitment. We extracted the zooplankton biomass to validate the models secondary production. Average numbers of individuals per square meter of the most dominant species (Calanoides carinatus and Calanus agulhensis) of copepods were converted in mg dry weight $\mathrm{m}^{-2}$ using living material [Painting et al., 1993] that had been oven dried at $60^{\circ} \mathrm{C}$ and weighed on a Cahn Model 25 Electrobalance [Peterson et al., 1990]. The dry weights were converted into nitrogen units using the following expression: $\mathrm{mg} \mathrm{N}=10 \% \mathrm{mg}$ dry weight. These abundance data include copepodites and adults obtained with net hauls operating over an average depth of $100 \mathrm{~m}$ [Verheye, 1991].

\section{Results and Discussion}

\subsection{Hydrodynamical Model Validation}

[23] The solution of the physical model has been analyzed in great details. The outcome has been the subject of several publications [Penven, 2000; Penven et al., 2001a, 2001b; Blanke et al., 2002a, 2002b; Lutjeharms et al., 2003]. A detailed model description and a general validation have been provided [Penven, 2000]. The seasonally averaged model results were successfully compared to the known averaged surface temperature, surface salinity, bottom temperature, bottom salinity, surface currents and integrated transport [Penven, 2000; Penven et al., 2001b]. Although the model was solely forced by a monthly climatology, the root mean square temperature, the root mean square sea surface elevation, the eddy kinetic energy and the velocityvariance ellipses are remarkably close to the observations [Penven, 2000; Penven et al., 2001b]. This confirms the predominant role of intrinsic oceanic instability processes for the variability in the southern Benguela [Penven, 2000; Penven et al., 2001b]. The generation of cyclonic eddies from the tip of the Agulhas Bank has been analyzed in detail [Penven et al., 2001a]. For this process, the model solution shows a great resemblance to surface observations, but also for in situ temperature sections [Penven et al., 2001a]. Comparisons with temperature vertical sections were also successfully performed across the Agulhas Bank [Lutjeharms et al., 2003]. It should nevertheless be noticed that the stratification simulated in the top few hundred meters is weaker than observed and so is the case in most of the model domain. On the Agulhas Bank, the model is 

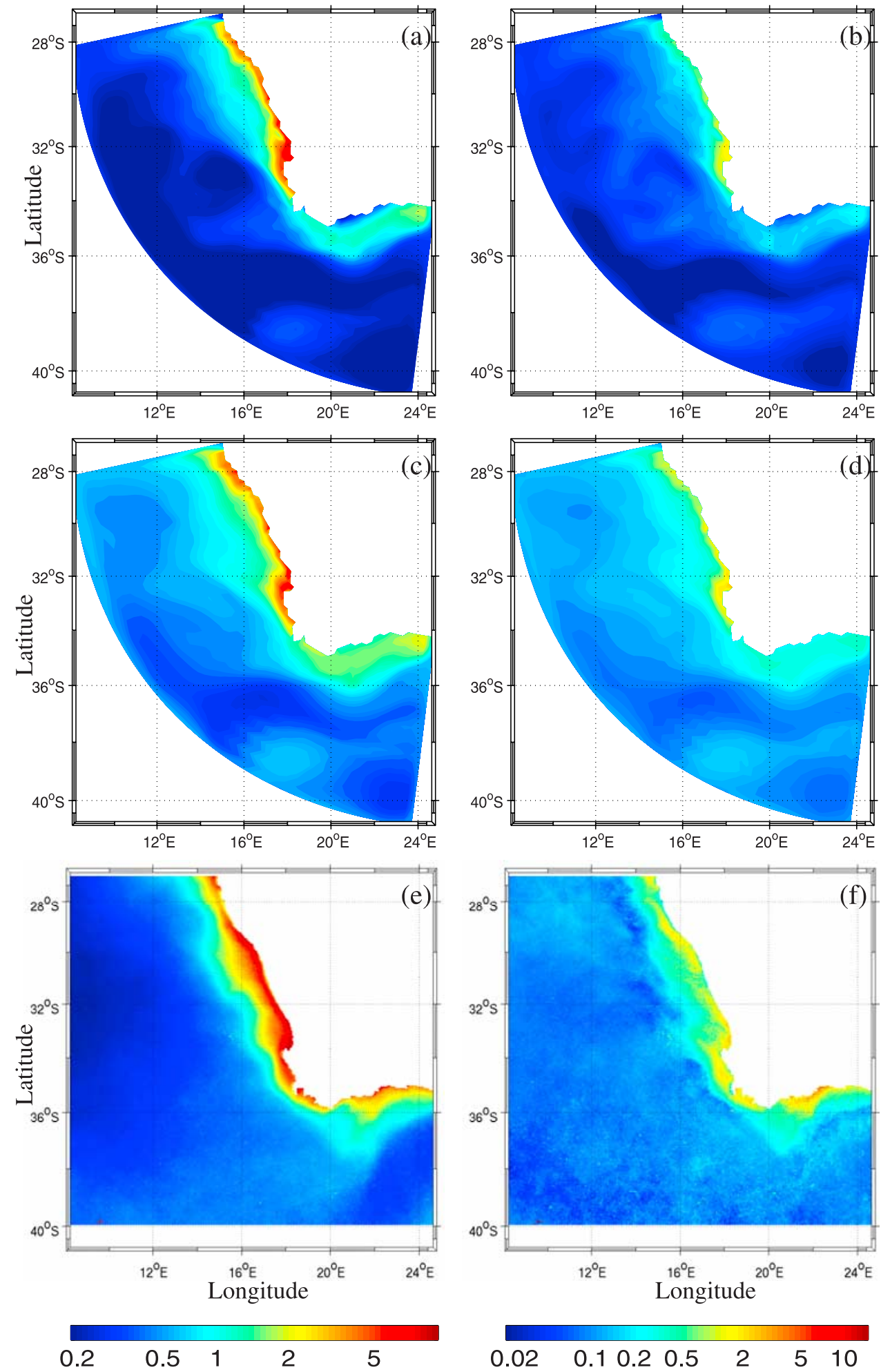

Figure 4. Annual distribution of the surface chlorophyll $a$ concentrations $\left(\mathrm{mg} \mathrm{Chla} \mathrm{m}^{-3}\right.$ ) averaged over the SeaWiFS attenuation depth: (a) SC model; (c) DC model; and (e) SeaWiFS data. Monthly variability of the surface chlorophyll $a$ : (b) SC model; (d) DC model; and (f) SeaWIFS data. 
able to reproduce with a great level of accuracy the seasonal variations in the vertical hydrographic structure as well as the generation of shear edge eddies [Lutjeharms et al., 2003]. If interannual variations are introduced in the surface model winds, our model is able to simulate the interannual variations of sea surface temperature in the southern Benguela with a precision of a few tenth degrees [Blanke et al., 2002a, 2002b].

[24] The main model/data discrepancies are a poor representation of the Agulhas variability and the Agulhas retroflection, and a too strong coastal upwelling due to the large-scale structure of the wind [Penven, 2000; Penven et al., 2001b]. The model version at a lower resolution does not represent properly the mesoscale dynamics as well as the detachment of the Agulhas current from the southern tip of the Agulhas Bank. Along the west coast, this does not affect strongly the large-scale upwelling structure [Penven, 2000]. Because of its execution speed, and because it represents the physical environment with a fair degree of accuracy [Penven, 2000], this version of the model is suitable for studying the phytoplankton dynamic by coupling a biogeochemical module.

\subsection{Annual Surface Distribution and Monthly Variability of Chlorophyll $a$}

[25] The annual distribution of the surface chlorophyll $a$ in the southern Benguela upwelling system simulated by the biogeochemical models and observed by SeaWiFS is presented in Figures $4 \mathrm{a}, 4 \mathrm{c}$, and $4 \mathrm{e}$. The main patterns observed by satellite are quite well reproduced by both models. Indeed, both biogeochemical models, i.e., SC and DC, are able to simulate high chlorophyll $a$ concentrations along the west coast and enriched concentrations on the Agulhas Bank. Both models give maximum values of chlorophyll $a$ concentrations close to $5 \mathrm{mg} \mathrm{Chla} \mathrm{m}^{-3}$ along the west coast, the highest values being associated to the retention zone of St. Helena Bay. Nevertheless, the offshore extension of modeled elevated concentrations associated to the intense upwelling-favorable zone is much reduced than the observed one.

[26] We can finally notice that the inshore/offshore chlorophyll $a$ gradient along the west coast is more marked in the SC version than in the DC one. This is partially due to the small phytoplankton organisms in the DC model which are able to grow in more oligotrophic regimes (not shown) as was shown by Booth and Smith [1997]. In this respect, the SC version would be preferable when compared with SeaWiFS.

[27] On the Agulhas Bank (between $34.5^{\circ} \mathrm{S}-37^{\circ} \mathrm{S}$ and $18^{\circ} \mathrm{E}-24^{\circ} \mathrm{E}$ ), both models underestimate the annual surface chlorophyll $a$ concentration in comparison with the SeaWiFS estimates. Values of up to $2 \mathrm{mg}$ Chla $\mathrm{m}^{-3}$ are provided by the models while the ocean color sensor yields values close to $3-4 \mathrm{mg}$ Chla $\mathrm{m}^{-3}$. The DC model seems however to perform better than the SC model since maxima are higher and the enrichment in pigment concentrations is more homogeneous, covering the whole Agulhas Bank. We tested the impact of a variable carbon/chlorophyll ratio on the chlorophyll $a$ distribution given by the SC model. Qualitative and quantitative interpretations did not change.
[28] To further document the ability of both versions to represent the time variability of the surface chlorophyll $a$ distribution, we tried to assess the monthly variability by computing the following standard deviation: $S D=\sqrt{\frac{1}{N} \sum\left(X_{i}-X_{y}\right)^{2}}$, where $X_{i}$ and $X_{y}$ represent the monthly and the annually averaged chlorophyll $a$ concentration, respectively. A general remark to be made is the underestimation by both model versions of the temporal variability in comparison with SeaWiFS (Figures $4 \mathrm{~b}, 4 \mathrm{~d}$, and $4 \mathrm{f})$. St. Helena Bay $\left(31^{\circ} \mathrm{S}-34^{\circ} \mathrm{S}\right)$ stands out since the modeled variability is of the correct order of magnitude. In the southern Benguela $\left(28^{\circ} \mathrm{S}-35^{\circ} \mathrm{S}\right)$ and in the Agulhas Bank region $\left(18^{\circ} \mathrm{E}-24^{\circ} \mathrm{E}\right)$, we can note a strong increase of variance between 0.02 offshore and 0.2 close to the coast in both model versions. None of the models is able to reproduce the high SeaWiFS variance (close to 10) over the Agulhas Bank, but the DC version behaves slightly better. The underestimation of the variability in our models is likely to be due to the monthly wind stress forcing that does not include the weekly pulses [Blanke et al., 2002b]. Another reason for this weak variability is the underestimation of high chlorophyll $a$ concentration along the west coast and on the Agulhas Bank. This overall underestimation is partly due to the weak stratification mentioned in section 4.1 which preclude the uplift of nutrient rich waters shallower enough.

\subsection{Seasonal Distribution of Chlorophyll $a$ 4.3.1. Horizontal Distribution}

[29] Austral summer (January-February-March) and winter (July August-September) distributions of simulated surface chlorophyll $a$ concentration and observed by SeaWIFS are shown in Figure 5. Summer and winter were chosen since they are enough separated in time to cover the overall temporal variability of the chlorophyll $a$ distribution, and the contrast between the two seasons is strong enough to emphasize the main seasonal features of the southern Benguela ecosystem.

[30] Both SC and DC models retrieve the main patterns, previously described, i.e., the highly productive west coast with concentrations of chlorophyll $a$ (about $10 \mathrm{mg}$ Chla $\mathrm{m}^{-3}$ ) in summer. The spatial location of the structures are in relatively good agreement with SeaWiFS observations but the peaks simulated by the SC and DC models are twice lower than those derived from SeaWIFS data $\left(20 \mathrm{mg} \mathrm{Chla} \mathrm{m}^{-3}\right)$. Nevertheless, the simulated maximum is consistent with the $\sim 16 \mathrm{mg}$ Chla $\mathrm{m}^{-3}$ concentrations estimated by Brown [1992]. The high concentrations of chlorophyll $a$ along the west coast are due to the intense upwelling activities around the area layering between $19^{\circ} \mathrm{S}$ and $33^{\circ} \mathrm{S}$ [Bakun, 1996]. St. Helena Bay has been recognized for some time as a highly productive area [Andrews and Hutchings, 1980; Touratier et al., 2003] where recruitment of anchovies and partly sardines occurs usually around May-June [Barange et al., 1999; Huggett et al., 2003]. East of Cape Town, the modeled upwelling does not produce chlorophyll $a$ concentrations as high as measured by SeaWiFS. This is probably due to the smoothing of wind speed imposed by a monthly forcing. 

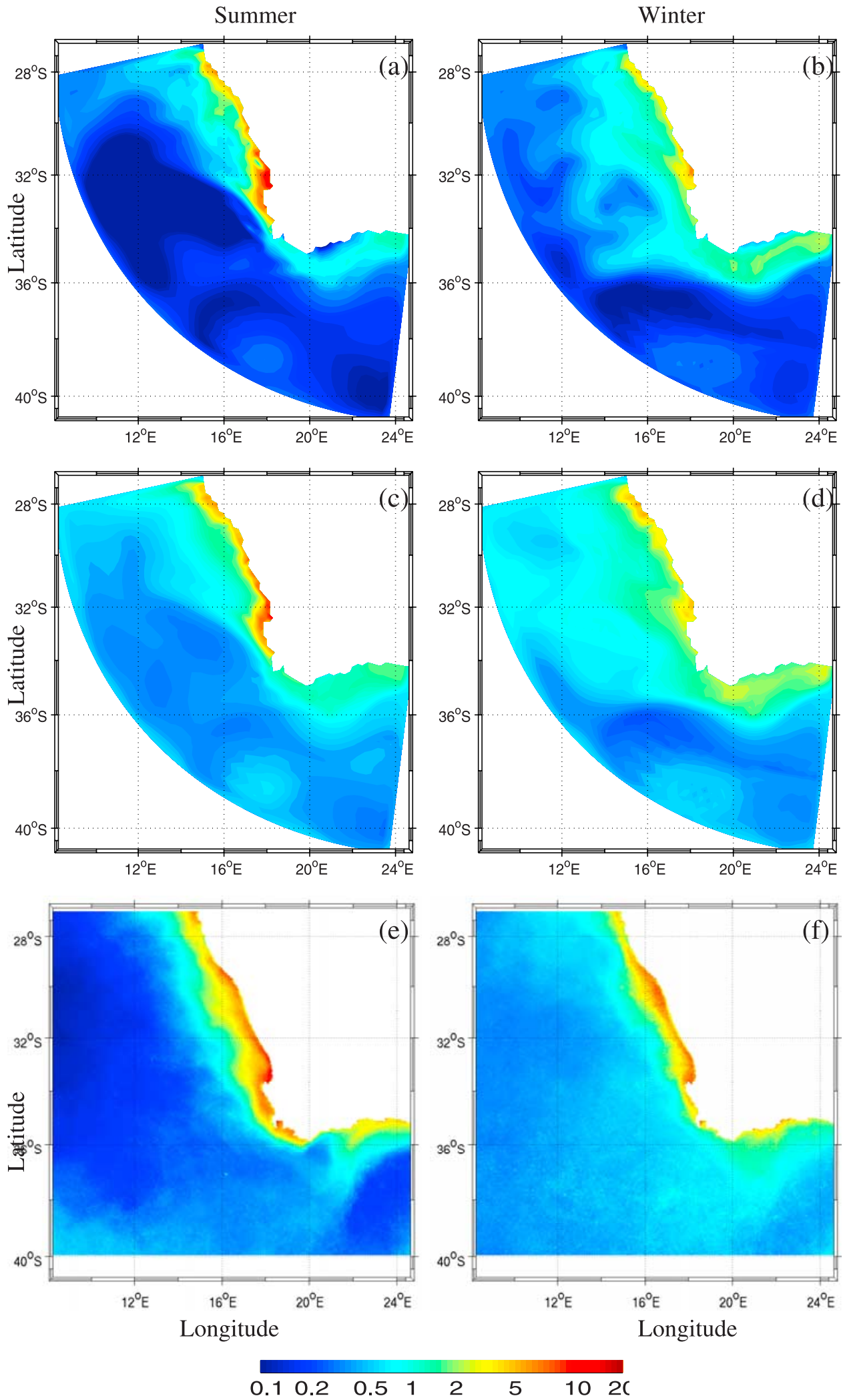

Figure 5. Seasonal distribution of the surface chlorophyll $a$ concentrations ( $\mathrm{mg}$ Chla $\mathrm{m}^{-3}$ ) averaged over the SeaWiFS attenuation depth: (a, b) SC model; (c, d) DC model, and (e, f) SeaWiFS data. 
[31] Penven et al. [2001b] showed that modeled SST at the coast was colder than observed from satellites in summer. They argued that by using a wind forcing from a monthly climatology, the smoothing of the high-frequency variability of the wind results in a continuous and persistent upwelling during the whole summer season. This feature modifies the inshore/offshore gradient of SST and hence the impact on nutrients (not shown) and chlorophyll $a$ distributions in both models; it explains the relative confinement of chlorophyll $a$ concentrations against the coast. Indeed, Waldron and Probyn [1992] and Demarcq et al. [2003] pointed out the strong relationship between sea surface temperature, nutrient input in the surface layers and the corresponding enrichment of phytoplankton in the Benguela upwelling. However, as mentioned for the annual distribution, the small phytoplankton compartment allows the DC model to simulate a broader strip of enriched phytoplankton than the SC model along the west coast.

[32] On the Agulhas Bank, the summer surface chlorophyll $a$ concentrations given by both biogeochemical models are lower than those along the western coast. In SeaWiFS images, concentrations of chlorophyll $a$ vary between 3 and $4 \mathrm{mg} \mathrm{Chla} \mathrm{m}^{-3}$ in summer. Concentrations simulated by both $\mathrm{SC}$ and DC models are much lower $(\sim 0.5$ and $\sim 1 \mathrm{mg}$ Chla $\mathrm{m}^{-3}$, respectively) and do not reproduce the same spatial pattern. Indeed, the observed rich-chlorophyll tongue extending from the coast toward the open sea at $23^{\circ} \mathrm{E}-34.5^{\circ} \mathrm{S}$ is absent from both simulations. In $\mathrm{SC}$, chlorophyll $a$ enrichment on the Agulhas Bank offers an arc shape with the lowest concentrations inshore. The monthly wind climatology used is responsible for the lowest concentrations on the Agulhas Bank and the use of daily wind forcing allows upwelling cells to develop close to the coast and therefore allows phytoplankton to grow (E. Machu, personal communication, 2004). The DC model produces chlorophyll concentration levels closer to those observed but remain weaker however. The observed dichotomy western/eastern Agulhas Bank is not reproduced by both models. This could be due to the fact that the Agulhas Current does not retroflect properly in this model configuration [Penven, 2000].

[33] In winter, chlorophyll $a$ concentrations decrease both in the simulation and in the observations (Figure 5). Maximum modeled chlorophyll $a$ concentration drops from 10 to $5 \mathrm{mg}$ Chla $\mathrm{m}^{-3}$ while SeaWiFS estimates are reduced from 20 to $10 \mathrm{mg}$ Chla $\mathrm{m}^{-3}$. During winter, upwelling is minimal in the southern Benguela [Shannon et al., 1984] since westward winds are dominating the wind forcing. Combined with lower insolation, these conditions induce lower chlorophyll $a$ concentrations simulated by both biogeochemical models. The contrast between winter and summer distribution of chlorophyll $a$ is then due to the decrease of upwelling intensity combined to the weak irradiance conditions. According to Shannon and O'Toole [1999], the insolation and upwelling season coincide in the west coast, which makes it highly productive in summer as compared to winter.

[34] The contrast in the chlorophyll concentration between the western coast and the Agulhas Bank described previously still remains but is weaker since chlorophyll concentrations decrease along the west coast. The spring season is announced by the coming back of strong southeasterly (upwelling favorable) winds. During the spring season (not shown), many of the phytoplankton distribution characteristics are similar to those in summer. More concentrated patches of chlorophyll $a$ start building up inshore off the west coast in spring, they become firmly established in summer, and then start tailing off in autumn, during which the chlorophyll distribution patterns become similar to those in winter.

[35] The functioning of the two subsystems (west coast and Agulhas Bank) differs and the contrast between both areas is pronounced. When comparing the dynamics of plankton on the west coast, the Agulhas Bank and the oceanic region, Moloney et al. [1991] made similar observations to those revealed by our models. Indeed, the Agulhas Bank is strongly stratified in summer, as a consequence nutrient concentrations are low in the euphotic layer [Shannon and O'Toole, 1999]. This induces lower chlorophyll concentrations.

[36] Both model versions produce different chlorophyll $a$ distribution between $18^{\circ} \mathrm{E}$ and $23^{\circ} \mathrm{E}$ over the Agulhas Bank. We attribute this difference to the biological model structure, and in particular to the double phytoplankton compartments. The DC version, by including a rudimentary representation of size classes, allows a more realistic biomass estimate. The standing stocks of phytoplankton communities of the Agulhas Bank are characterized by different size classes [Moloney et al., 1991]. Moloney et al.'s results have been validated by detailed studies by McMurray et al. [1993], in which it was noted that the Agulhas Bank did not have as stable a summer community as had been generally believed.

\subsubsection{Vertical Distribution Around the Southwestern Cape}

[37] Vertical sections along the transect $32.8^{\circ} \mathrm{S}-17.8^{\circ} \mathrm{E}$ and $33^{\circ} \mathrm{S}-16^{\circ} \mathrm{E}$ have been selected to display the vertical distributions of chlorophyll during winter (August models outputs) and summer (January models outputs) conditions on the west coast. During winter, both SC and DC models show

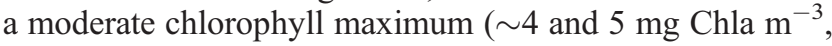
respectively) in the upper $20 \mathrm{~m}$ depth of the water column along the coast (Figures 6a and 6c). This maximum

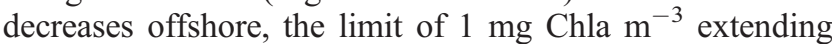
farther offshore for the DC model $(>170 \mathrm{~km})$ than for the SC model $(\sim 130 \mathrm{~km})$. Along the same latitude, Shannon et al. [1984] found in winter well-mixed, chlorophyll-poor waters intruding close inshore, with weak frontal gradients. They also noted a moderate maximum of subsurface chlorophyll occurring offshore, not seen in the average August vertical distribution. Offshore, in the upper $40 \mathrm{~m}$ of the model domain, the concentrations simulated by the SC model are lower than those simulated by the DC model. This is due to the small phytoplankton compartment of the DC model presenting high values offshore (Figure 6e).

[38] During summer, a strong inshore/offshore gradient develops in the upper ocean layer. Concentrations of $\sim 20 \mathrm{mg}$ Chla $\mathrm{m}^{-3}$ at the coast decrease to concentrations lower than $0.5 \mathrm{mg}$ Chla $\mathrm{m}^{-3} 120 \mathrm{~km}$ offshore. At the same time, a deepening of the maximum concentration occurs 

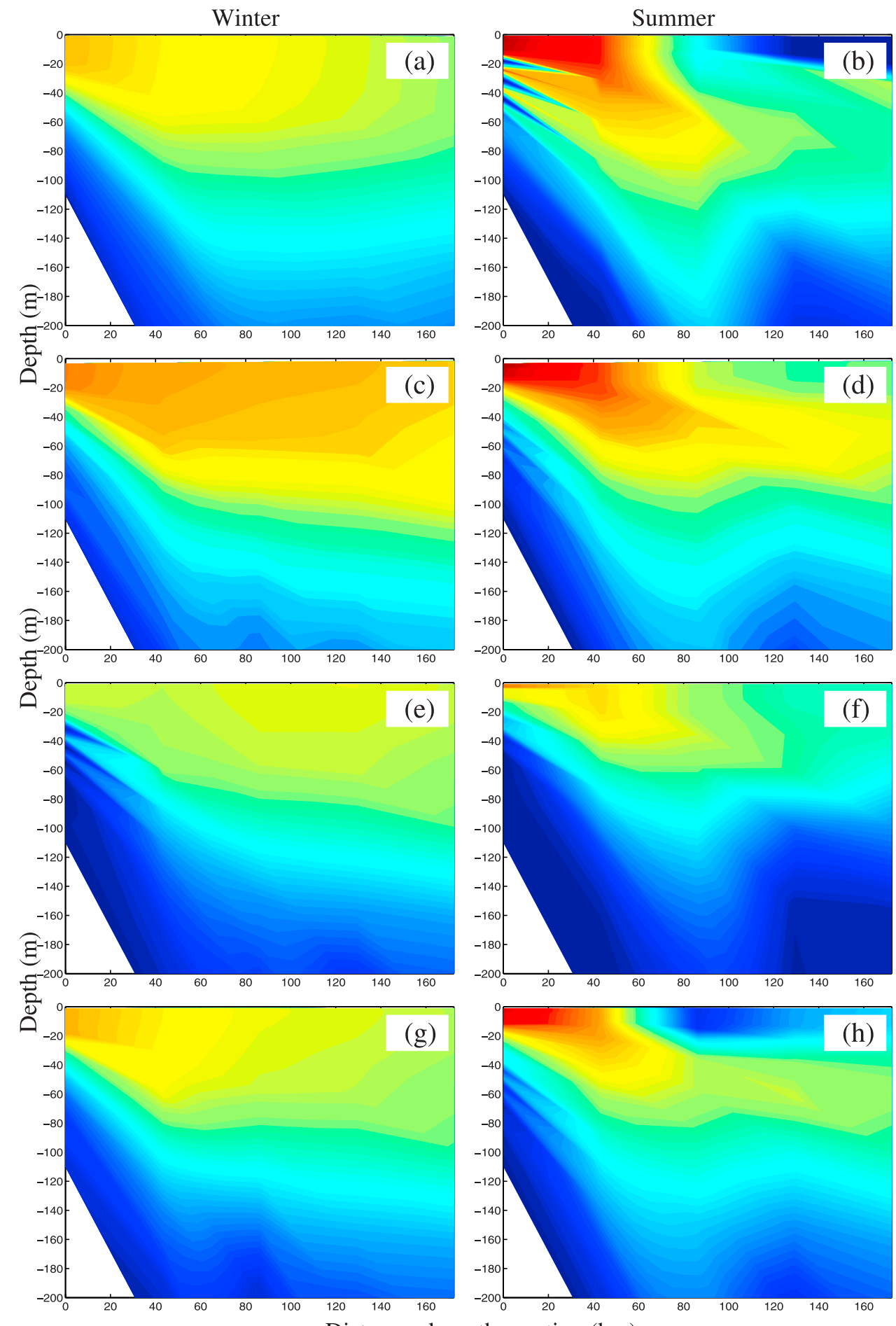

Distance along the section $(\mathrm{km})$

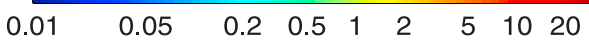

Figure 6. Vertical section of chlorophyll $a$ concentrations $\left(\mathrm{mg} \mathrm{Chla} \mathrm{m}^{-3}\right)$ along the transect between $32.8^{\circ} \mathrm{S}-17.8^{\circ} \mathrm{E}$ and $33^{\circ} \mathrm{S}-15.9^{\circ} \mathrm{E}$ on the west coast: (a, b) SC model and (c, d) total chlorophyll $a$ DC model; (e, f) chlorophyll $a$ derived from small phytoplankton; and $(\mathrm{g}, \mathrm{h})$ chlorophyll $a$ derived from large phytoplankton. 

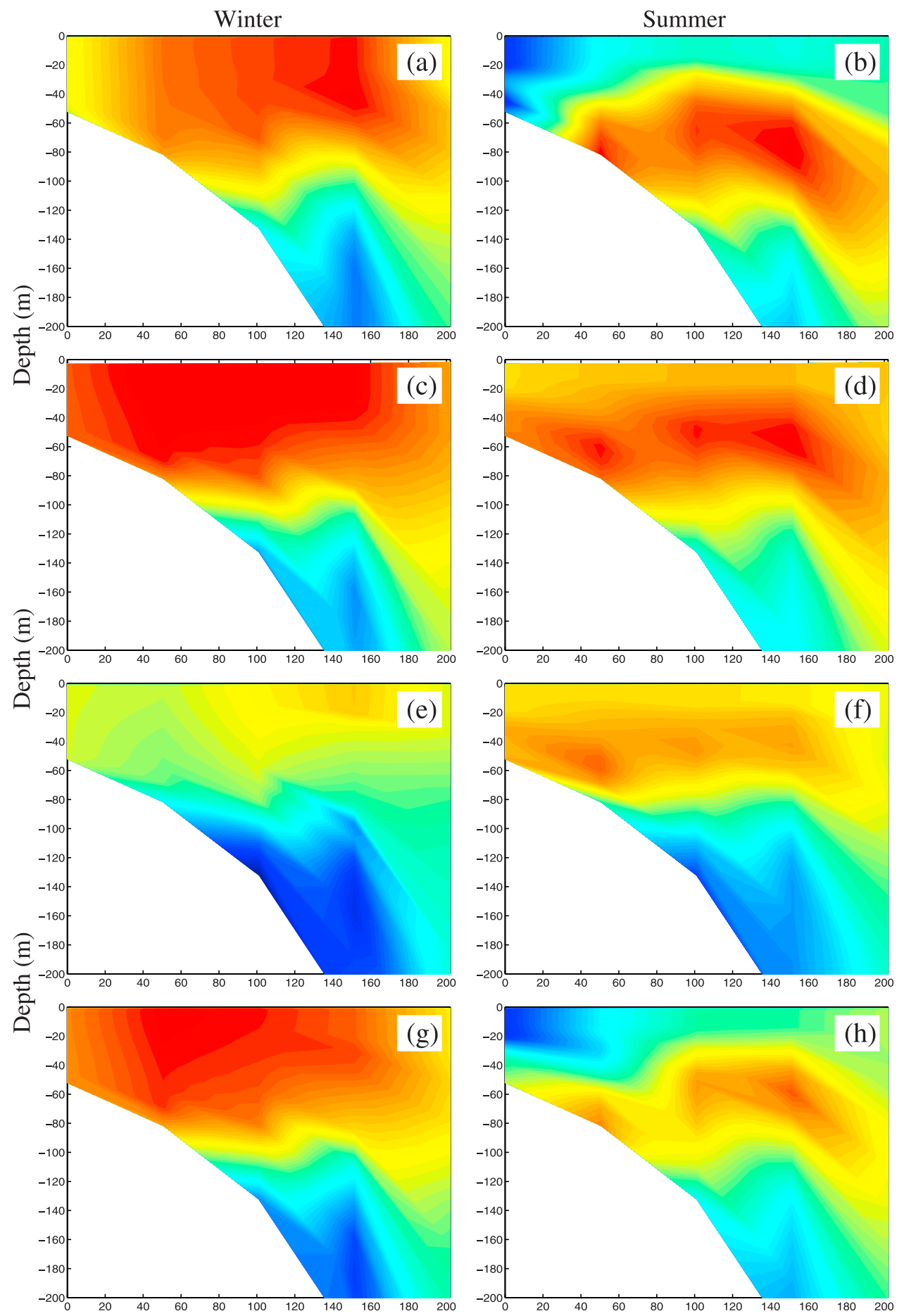

Distance along the section $(\mathrm{km})$

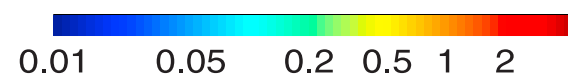

Figure 7. Vertical section of chlorophyll $a$ concentrations $\left(\mathrm{mg} \mathrm{Chla} \mathrm{m}^{-3}\right)$ along the transect between $34.59^{\circ} \mathrm{S}-20.6^{\circ} \mathrm{E}$ and $36.4^{\circ} \mathrm{S}-20.6^{\circ} \mathrm{E}$ over the Agulhas Bank: (a, b) SC model; (c, d) total chlorophyll $a$ DC model; (e, f) chlorophyll $a$ derived from small phytoplankton; and ( $\mathrm{g}, \mathrm{h}$ ) chlorophyll $a$ derived from large phytoplankton. 


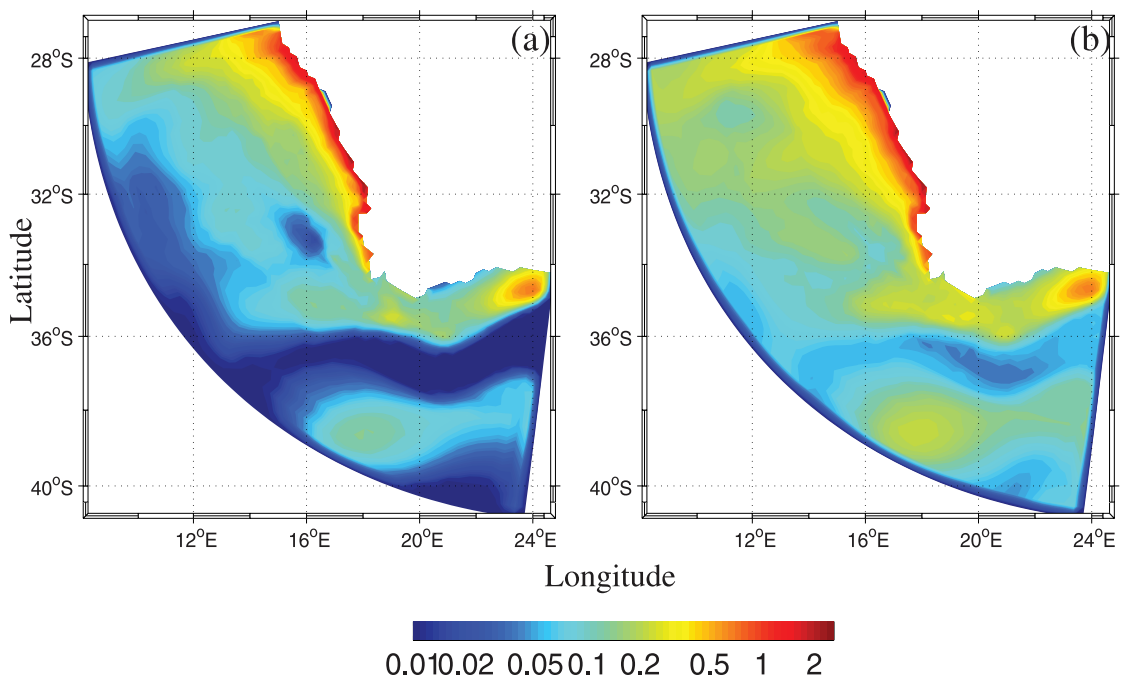

Figure 8. Simulated annual primary production in the Benguela upwelling system $\left(\mathrm{g} \mathrm{C} \mathrm{m}^{-2} \mathrm{~d}^{-1}\right)$ in the upper $65 \mathrm{~m}$ : (a) SC model and (b) DC model.

when moving offshore giving a well-known subsurface maximum in oligotrophic subtropical waters. Both models reproduce these patterns which have been observed by Shannon et al. [1984] and confirmed by Mitchell-Innes et al. [2000]. The chlorophyll a (derived from large phytoplankton) distribution patterns (Figures $6 \mathrm{~g}$ and $6 \mathrm{~h}$ ) seem very similar to those displayed by the SC model during both summer and winter. As mentioned previously, higher offshore concentrations simulated by the DC model in the upper $40 \mathrm{~m}$ result from the small phytoplankton compartment. Nevertheless, small phytoplankton concentrations are weaker during the summer season, when nutrients do not reach the well-lit surface layers.

\subsubsection{Vertical Distribution on the Agulhas Bank}

[39] Vertical sections of simulated chlorophyll $a$ concentrations along the transect between $34.6^{\circ} \mathrm{S}-20.6^{\circ} \mathrm{E}$ and $36.4^{\circ} \mathrm{S}-20.6^{\circ} \mathrm{E}$ are shown in Figure 7. During winter, both models produce an homogeneous chlorophyll distribution. This is due to the winter storms which mix the water down to the bottom. Shannon et al. [1984] showed that temperatures exhibit variation smaller than $0.6^{\circ} \mathrm{C}$ over the whole water column. As mentioned in the previous section, the SC model presents a pronounced minimum at the coast and at $200 \mathrm{~km}$ offshore. This second minimum corresponds to the nutrient-poor Agulhas Current waters.

[40] During summer, both SC and DC models simulate a subsurface maximum around $60 \mathrm{~m}$ correlated to the vertical temperature structure (not shown) in agreement with observations made by Shannon et al. [1984]. Indeed, in this case, the phytoplankton is maintained by a balance between light limitation and nutrient diffusion, associated with a slow rate of turnover. The thickness of this subsurface enriched layer is about $40 \mathrm{~m}$. South of $160 \mathrm{~km}$ offshore, this maximum layer deepens. Differences between Figures $7 \mathrm{~b}$ and $8 \mathrm{~d}$ are mainly linked to the small phytoplankton distribution (Figure 7f) simulated by the DC model since large DC phytoplankton (Figure 7h) and SC phytoplankton behave similarly. Hence the phytoplankton production on the Agulhas Bank is largely controlled by thermocline/ nitracline dynamics [Shannon and O'Toole, 1999] and differs notably from the west coast dynamics.

\subsection{Primary Production}

[41] The modelled primary production in units of $\mathrm{gC} \mathrm{m}^{-2}$ $\mathrm{d}^{-1}$ is computed using a conventional value of the Redfield $\mathrm{C} / \mathrm{N}$ ratio of 6.625 . The phytoplankton growth rates (equations (5) for the SC model and the product of equation (3) and the sum of the terms of equation (11) for the DC model) are integrated in time and then averaged every 5 days during the models run. In the DC model, the primary production is the sum of the new production based on the nitrate uptake [Dugdale and Goering, 1967] and the regenerated production based on the ammonium uptake for both classes of phytoplankton organisms. The simulated annual primary production ranges between 1 to $\sim 2 \mathrm{gC} \mathrm{m}^{-2} \cdot \mathrm{d}^{-1}$ along the western coast from $28^{\circ} \mathrm{S}$ to $35^{\circ} \mathrm{S}$ in both SC and DC models (Figures $8 \mathrm{a}$ and $8 \mathrm{~b}$ ). The maximum value of primary production given by both models is about $2.6 \mathrm{gC} \mathrm{m}^{-2}$ $\mathrm{d}^{-1}$ in the intensive upwelling areas (St. Helena Bay and around Oranjemund). This value is similar to the estimation of $2.5 \mathrm{gC} \mathrm{m}^{-2} \mathrm{~d}^{-1}$ made by Carr [2002] over the euphotic zone (1\% light level). For the southern Benguela upwelling system $\left(31^{\circ} \mathrm{S}-36^{\circ} \mathrm{S}\right)$, Shannon and Field [1985] obtained an averaged production of $2.8 \mathrm{gC} \mathrm{m}^{-2} \mathrm{~d}^{-1}$ in the upper 40 m. Ware [1992] calculated an annual Benguela production between $20^{\circ} \mathrm{S}$ and $35^{\circ} \mathrm{S}$ of $2 \mathrm{gC} \mathrm{m}^{-2} \mathrm{~d}^{-1}$, Shannon and $O^{\prime}$ Toole [1999] have found similar value between $28^{\circ} \mathrm{S}$ and $34^{\circ}$ S. Pitcher and Boyd [1996] estimated a primary production rate of 2.14 and $3.92 \mathrm{gC} \mathrm{m}^{-2} \cdot \mathrm{d}^{-1}$ from determinations of $\mathrm{NO}_{3}-\mathrm{N}$ depletion and a phytoplankton biomass-nutrient $\left(\mathrm{NO}_{3}-\mathrm{N}\right)$ consumption equation, respectively. Therefore both models are able to simulate properly the measured and/or satellite derived primary production in the Benguela upwelling region. 

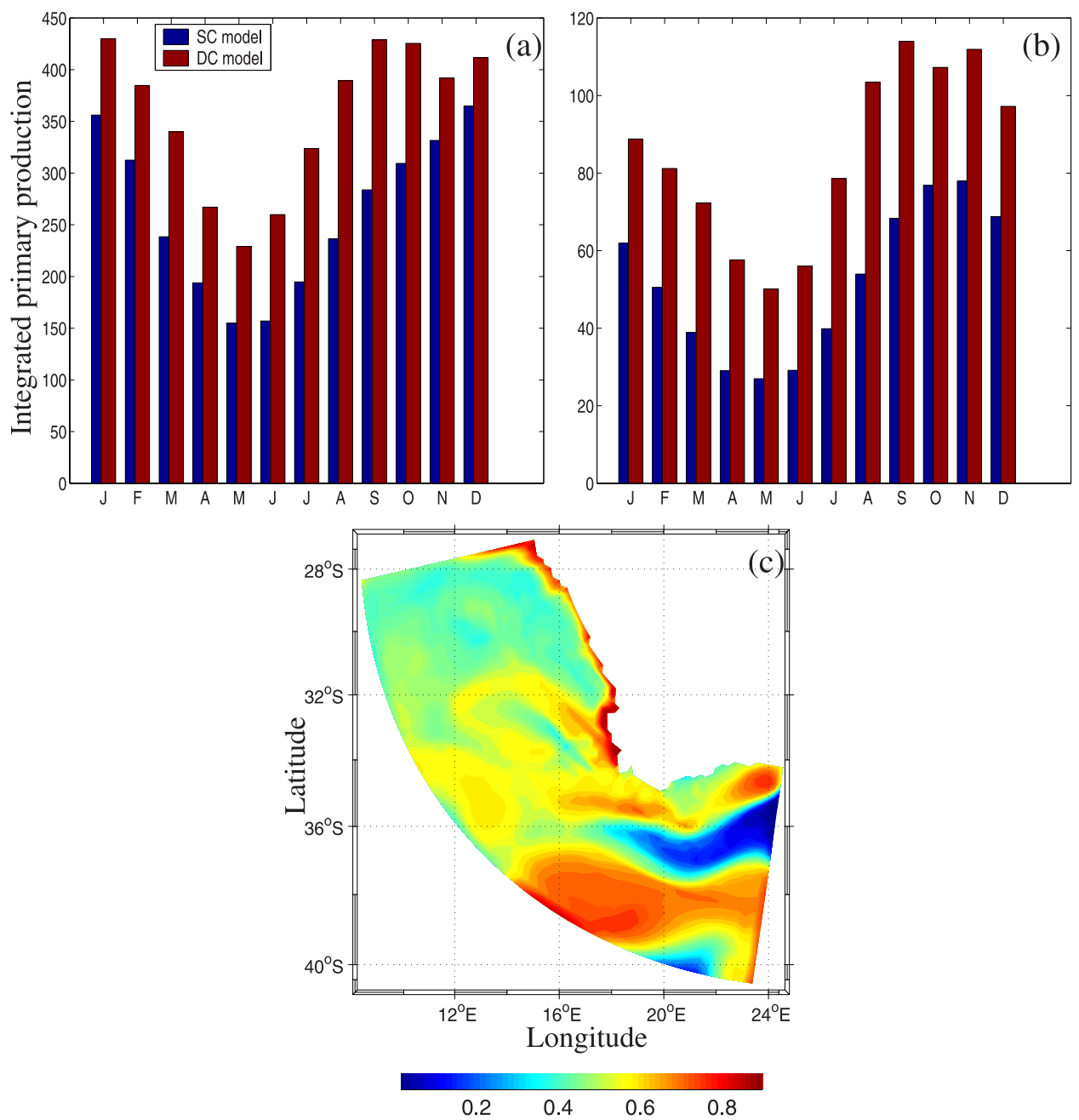

Figure 9. Total primary production $\left(\mathrm{g} \mathrm{C} \mathrm{m}^{-2} \mathrm{~d}^{-1}\right)$ in the model domain: (a) in the west coast $\left(28^{\circ} \mathrm{S}-\right.$ $40^{\circ} \mathrm{S}$ and $\left.8^{\circ} \mathrm{E}-18^{\circ} \mathrm{E}\right)$ and (b) over the Agulhas Bank $\left(34^{\circ} \mathrm{S}-40^{\circ} \mathrm{S}\right.$ and $\left.18^{\circ} \mathrm{E}-24.5^{\circ} \mathrm{E}\right)$. (c) Annual simulated $\mathrm{f}$ ratio for DC model.

[42] The boundary of $1 \mathrm{gC} \mathrm{m}^{-2} \mathrm{~d}^{-1}$ given by the DC model extends farther offshore than that of the SC model (Figures $8 \mathrm{a}$ and $8 \mathrm{~b}$ ). Primary production patterns roughly reflect the overall chlorophyll distribution patterns with a strong inshore/offshore gradient (maximum of $2.6 \mathrm{gC} \mathrm{m}^{-2} \mathrm{~d}^{-1}$ near the coast to $0.01 \mathrm{gC} \mathrm{m}^{-2} \mathrm{~d}^{-1}$ in Cape Basin), and a contrast between the West Coast and the Agulhas Bank. A lower production is observed over the Agulhas Bank except the area between $22^{\circ} \mathrm{E}$ and $24^{\circ} \mathrm{E}$ where it reaches $\sim 0.5 \mathrm{gC} \mathrm{m}^{-2} \mathrm{~d}^{-1}$. Offshore the Agulhas Bank, the primary production simulated by the SC model $\left(\sim 0.1 \mathrm{gC} \mathrm{m}^{-2} \mathrm{~d}^{-1}\right)$ is twice as low than the primary production simulated by the DC model $\left(\sim 0.2 \mathrm{gC} \mathrm{m}^{-2} \mathrm{~d}^{-1}\right)$.

[43] On the west coast of Africa, both SC and DC models simulate a maximum primary production in January (Figure 9a). Integrated production in the whole model domain of $430 \mathrm{gC} \mathrm{m}^{-2} \mathrm{~d}^{-1}$ and $350 \mathrm{gC} \mathrm{m}^{-2} \mathrm{~d}^{-1}$ are given for the west coast by the DC and SC models, respectively. A second maximum occurs in spring (September-October) in the DC model, absent from the SC simulation. The lowest values correspond to the fall season (May for DC and MayJune for SC). Primary production is higher all yearlong for the DC model reflecting the resource of an additional nutrient (ammonium). On the Agulhas Bank, both models give a maximum production in spring and a minimum in fall (Figure 9b).

[44] Let us now examine the annual $\mathrm{f}$ ratio (new/total production) given by the DC model (Figure 9c). Within the core of the upwelling along the western coast, the f ratio is around 0.8 meaning that $80 \%$ of the primary production is derived from new production. The mean annual $f$ ratio estimated by Waldron et al. [1997] is 0.73 and the estimation made by Shannon and Field [1985] for the Cape Columbine/St. Helena Bay is in the same range $(0.72)$. The contribution of the new production to the total primary production decreases from $80 \%$ inshore to less than $40 \%$ offshore where the system becomes oligotrophic. It implies that the offshore areas are dominated by regenerated production. According to Hutchings et al. [1995], f ratios higher than 0.5 are typical of coastal upwelling systems 

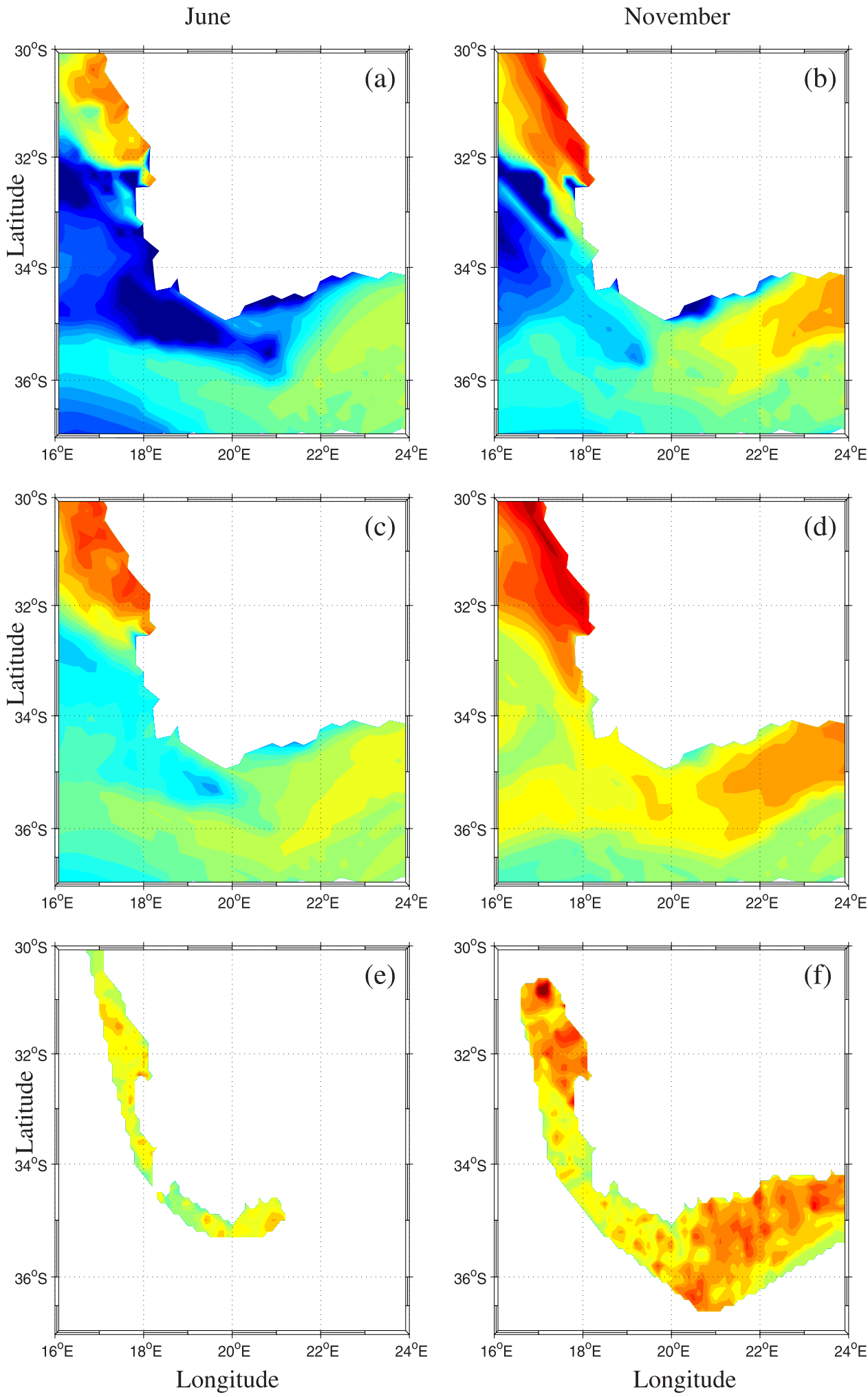

\section{$0.010 .050 .2 \quad 1251030100$}

Figure 10. Horizontal distribution of zooplankton biomass $\left(\mathrm{mmol} \mathrm{N} \mathrm{m}{ }^{-2}\right)$ integrated over the top $100 \mathrm{~m}$. For the SC model: (a) June and (b) November; for the DC model: (c) June and (d) November; and for in situ data (monthly climatology 1988/2000): (e) June and (f) November. 
dominated by diatoms. This supports the DC model results in which large phytoplankton (representing mainly diatoms) distributions (not shown) remain concentrated along the coast and produce high $\mathrm{f}$ ratio values in Figure 9c. Other studies confirm that the small microplankton is generally more important than large plankton in regenerated systems [Glibert et al., 1982; Probyn, 1987]. The SC model, owing to the absence of a small size phyto-compartment and an ammonium pool, cannot reproduce properly the dynamics of oligotrophic regime (offshore) where remineralization processes and small autotrophs are important. Photosynthesis-irradiance and half-saturation nutrient uptake constants are most likely a function of species composition/cell size. The increase in nitrate favors the increase in the abundance of large cells (with high $K_{N_{3}}$ ) and consequently the increase of $f$ ratio during upwelling events. Later, as nitrate becomes depleted, smaller organisms (flagellates) with lower $\mathrm{K}_{\mathrm{NO}_{3}}$ would be favored. This species shift is missing in the SC model.

[45] On the Agulhas Bank, f ratio ranges between 0.5 and 0.7 along the $200-\mathrm{m}$ isobath (Figure 9c). On the eastern Agulhas Bank $\left(33^{\circ} \mathrm{S}, 22^{\circ} \mathrm{E}-24.5^{\circ} \mathrm{E}\right)$ the high $\mathrm{f}$ ratio $(\sim 0.7)$ correspond to the enrichment by a shear edge eddy [Lutjeharms et al., 2003]. On the central Agulhas Bank $\left(20^{\circ} \mathrm{E}-23^{\circ} \mathrm{E}, 34^{\circ} \mathrm{S}\right), \mathrm{f}$ ratio decreases to 0.4 underlining a regenerated regime. In the area between $34^{\circ} \mathrm{S}-36^{\circ} \mathrm{S}$ and $11^{\circ} \mathrm{E}-16^{\circ} \mathrm{E}$, the contribution of the new production is around $60 \%$, in opposition with what we would expect for an oligotrophic region. Eddies pinched off the Agulhas retroflection and in the lee of the Agulhas Bank [Penven et al., 2001a] induce vertical movements which bring nitrate-rich waters from the ocean interior to the surface.

[46] Probyn [1992] reviewed the available f ratios measured in the southern Benguela: the range is consistent with that of the model, but the mean value given by Probyn [1992] is only 0.39 , consistent with the mean value $(0.2-$ 0.3) given by Shannon and O'Toole [1999]. The mean value computed in the whole model domain is 0.51 . It appears clearly that the model overestimates the f ratio, but Probyn [1992] measured a regional $f$ ratio of 0.64 during a maximum growth phase in the southern Benguela. According to him, this higher $\mathrm{f}$ ratio is a consequence of a bloom which was dominated by large phytoplankton cells as it was the case in the DC model simulation. The 0.64 value is far from the range of $0.23-0.31$ given by Waldron and Probyn [1992], showing that it is difficult to settle once and for all on this topic. Macroscale observations show that the southern Benguela ecosystem is dominated by small phytoplankton cells (f ratio ranging between 0.2 and 0.3 [Probyn, 1992; Shannon and O'Toole, 1999]). From mesoscale observations however, when the system is dominated by large phytoplankton cells, the classical and almost linear food chain (i.e., $\mathrm{NO}_{3}$-diatoms-mesozooplankton) becomes relatively more important and the f ratio increases [Touratier et al., 2003].

\subsection{Spatiotemporal Distribution of Zooplankton}

\subsubsection{Horizontal Distribution}

[47] Copepods play an important role in the trophic functioning of the Benguela ecosystem. They are the prin- cipal food of anchovies in the southern Benguela and have been the most studied groups. Let us examine the horizontal distributions of the modeled zooplankton biomass, integrated over the top $100 \mathrm{~m}$ in both SC and DC versions for the June and November months (Figure 10). For the DC configuration, only the large zooplankton biomass distribution is shown for comparison with the derived in situ climatology.

[48] In autumn (June), zooplankton standing stocks provided on the west Coast by both SC and DC models are overestimated as compared with the climatology estimate. Values reach $50 \mathrm{mmol} \mathrm{N} \mathrm{m}^{-2}$ north of St. Helena Bay whereas zooplankton observations indicate a 5 to $10 \mathrm{mmol}$ $\mathrm{N} \mathrm{m}^{-2}$ range. However, in two locations, St. Helena Bay and in the area between $31^{\circ} \mathrm{S}-17^{\circ} \mathrm{E}$ and $31.7^{\circ} \mathrm{S}-17.5^{\circ} \mathrm{E}$, models and data seem in good agreement. Both models show an offshore extension in zooplankton biomass which is probably unrealistic although data does not cover offshore, the DC model having an even larger offshore extension. This may clearly be attributed to the prey distribution extending too far offshore in the DC model, and might be exacerbated by the absence of vertical migration in the model. Indeed, by migrating in the upwelling undercurrent, zooplankton can limit its offshore advection [Gibbons et al., 1991; Batchelder et al., 2002]. From Cape Columbine to the Agulhas Bank, zooplankton biomass is underestimated. The DC model behaves better by producing a moderate zooplankton biomass $(0.2-2 \mathrm{mmol} \mathrm{N}$ $\left.\mathrm{m}^{-2}\right)$ closer to in situ data $\left(0.5-5 \mathrm{mmol} \mathrm{N} \mathrm{m}^{-2}\right)$.

[49] In late austral spring (November), both spatial distribution and abundance of zooplankton provided by the DC model are remarkably similar to those of in situ observations. Elevated zooplankton concentrations are found north of $33^{\circ} \mathrm{S}$ along the west coast (up to $100 \mathrm{mmol} \mathrm{N} \mathrm{m}{ }^{-2}$ ) and over the Agulhas Bank between $21^{\circ} \mathrm{E}$ and $24^{\circ} \mathrm{E}$ (up to $50 \mathrm{mmol} \mathrm{N} \mathrm{m}{ }^{-2}$ ), in full agreement with the climatological zooplankton biomass distribution. The zooplankton biomass simulated by the SC model does not reach the observed levels in the area between $17^{\circ} \mathrm{E}$ and $22^{\circ} \mathrm{E}$, indicating a strong underestimation.

\subsubsection{Seasonal Cycle of Integrated Zooplankton}

[50] Figure 11 presents the time evolution of the zooplankton biomass inshore (area 1 and area 2) and offshore (area 3) along the west coast and inshore on the central Agulhas Bank (area 4). The coordinates of the different areas considered are reported in Table 5. It is clear that zooplankton exhibits a marked variability, both in space and time. Inshore, along the west coast, in area 1 around Hondeklip Bay $\left(30^{\circ} \mathrm{S}-17^{\circ} \mathrm{E}\right)$ and area 2 between Cape Town and Cape Columbine, the seasonal cycles of zooplankton biomass differ. Within area 1, a maximum occurs in late summer and both SC and DC models behave similarly. Farther south (area 2; South of Cape Columbine), the large zooplankton biomass of the DC model exhibits two marked maxima $\left(30-32 \mathrm{mmol} \mathrm{N} \mathrm{m}{ }^{-2}\right)$, one in spring and another one in late summer, while small zooplankton biomass is maximum in early spring (about $26 \mathrm{mmol} \mathrm{N} \mathrm{m}^{-2}$ ). Andrews and Hutchings [1980] conducted a monitoring line corresponding to area 2 from October 1970 to March 1973 and obtained the same bimodal pattern in phase 

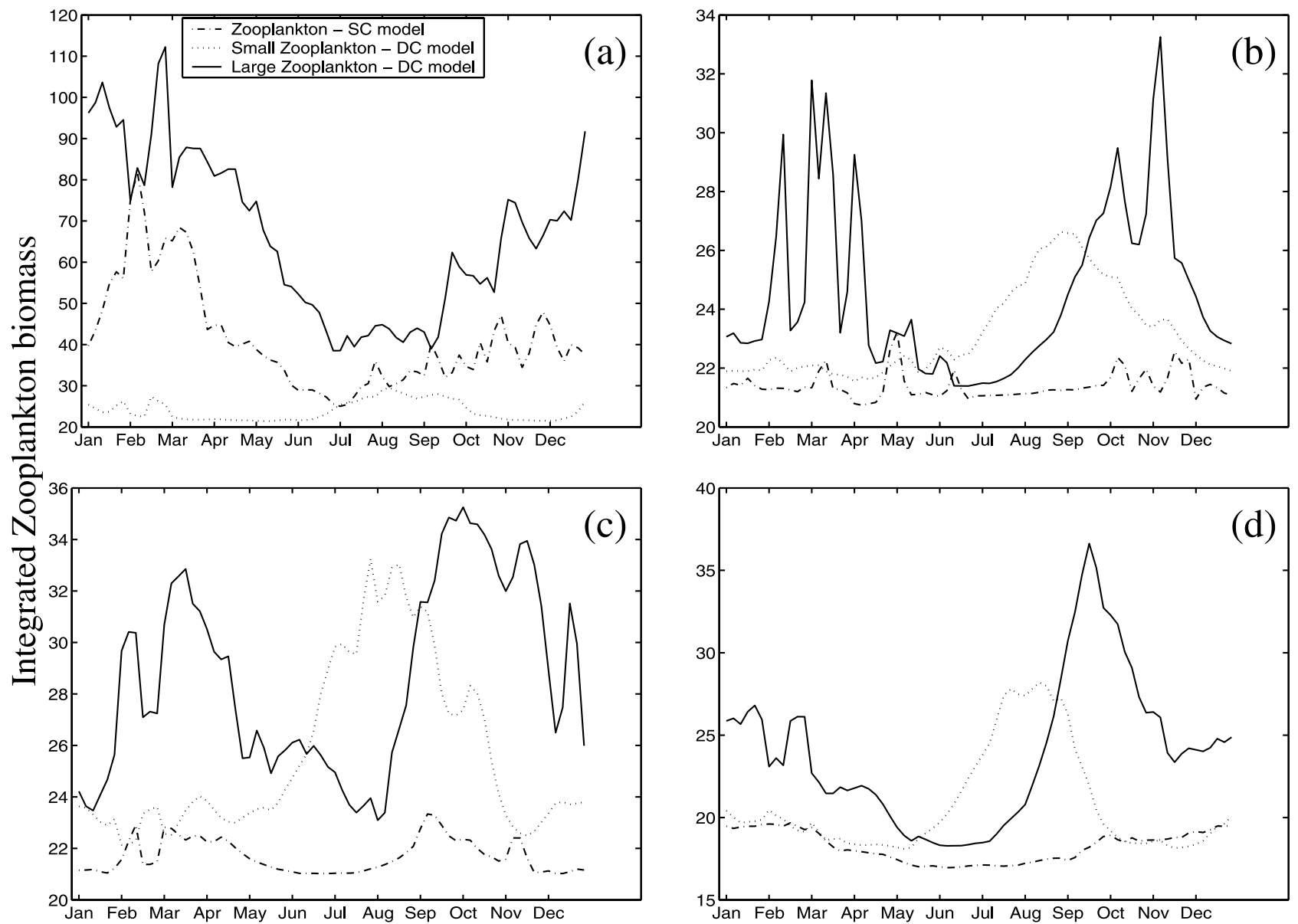

Figure 11. Mean annual cycle of zooplankton biomass $\left(\mathrm{mmol} \mathrm{N} \mathrm{m}^{-2}\right)$ integrated over the top $100 \mathrm{~m}$. (a) West coast, area 1. (b) West coast, area 2. (c) West coast, area 3. (d) Agulhas Bank, area 4. (See Table 5 for the definition of the different areas.)

with the DC model outputs for the first year of observations whereas a unique late spring maximum occurred the second year. Maximum values ranged from 4 to $5 \mathrm{~g}$ dry weight $\mathrm{m}^{-2}$ corresponding to $28-36 \mathrm{mmol} \mathrm{N} \mathrm{m}^{-2}$, hence in agreement with the DC results.

[51] SC's maximum zooplankton biomass is one third smaller (22 mmol $\mathrm{N} \mathrm{m}^{-2}$; Figure 11c) and varies much less seasonaly, mainly due to the weaker zooplankton biomass in this area (Figure 10). Moreover, the variability is out of phase with the biomass estimated by the DC model. This discrepancy between the two biogeochemical model configurations is important since this southern part of the west coast corresponds to the route of pelagic fish larvae from their spawning area (Agulhas Bank) to their nursery area (St. Helena Bay); it will then impact on their survival rate. Within area 3 , situated around $400 \mathrm{~km}$ offshore, the evolution of the zooplankton biomass in both models matches area 2 displaying two distinct maxima in spring and late summer even if the SC model biomass is smaller.

[52] On the Agulhas Bank (area 4), small zooplankton biomass peaks in late winter followed by large zooplankton in early spring (Figure 11d). From in situ data (Figure 10),

Table 5. Coordinates of the Different Points Selected in the Model Domain for the Mean Annual Cycle of Zooplankton Biomass

\begin{tabular}{|c|c|c|c|c|c|c|}
\hline & $P_{1}$ & $P_{2}$ & $P_{3}$ & $P_{4}$ & $P_{5}$ & \\
\hline $\begin{array}{l}\text { Area } 1 \\
\text { Area } 2 \\
\text { Area } 3\end{array}$ & $\begin{array}{l}30^{\circ} \mathrm{S}-16^{\circ} \mathrm{E} \\
33^{\circ} \mathrm{S}-16^{\circ} \mathrm{E} \\
30^{\circ} \mathrm{S}-12^{\circ} \mathrm{E}\end{array}$ & $\begin{array}{c}30^{\circ} \mathrm{S}-17^{\circ} \mathrm{E} \\
33^{\circ} \mathrm{S}-17.8^{\circ} \mathrm{E} \\
30^{\circ} \mathrm{S}-13.2^{\circ} \mathrm{E}\end{array}$ & $\begin{array}{r}\text { West Coast } \\
30.6^{\circ} \mathrm{S}-16.5^{\circ} \mathrm{E} \\
33.5^{\circ} \mathrm{S}-16.95^{\circ} \mathrm{E} \\
30.6^{\circ} \mathrm{S}-12.65^{\circ} \mathrm{E}\end{array}$ & $\begin{array}{c}31.2^{\circ} \mathrm{S}-16^{\circ} \mathrm{E} \\
34^{\circ} \mathrm{S}-16^{\circ} \mathrm{E} \\
31.2^{\circ} \mathrm{S}-12^{\circ} \mathrm{E}\end{array}$ & $\begin{array}{c}31.2^{\circ} \mathrm{S}-17^{\circ} \mathrm{E} \\
34^{\circ} \mathrm{S}-17.8^{\circ} \mathrm{E} \\
31.2^{\circ} \mathrm{S}-13.2^{\circ} \mathrm{E}\end{array}$ & $\begin{array}{l}\text { inshore } \\
\text { inshore } \\
\text { offshore }\end{array}$ \\
\hline Area 4 & $35^{\circ} \mathrm{S}-19.2^{\circ} \mathrm{E}$ & $35^{\circ} \mathrm{S}-20.8^{\circ} \mathrm{E}$ & $\begin{array}{l}\text { Agulhas Bank } \\
35.35^{\circ} \mathrm{S}-20^{\circ} \mathrm{E}\end{array}$ & $35.7^{\circ} \mathrm{S}-19.2^{\circ} \mathrm{E}$ & $35.7^{\circ} \mathrm{S}-20.8^{\circ} \mathrm{E}$ & inshore \\
\hline
\end{tabular}


June biomass (winter) is 5 to 10 times lower than in November (spring), in agreement with model simulations.

\subsection{Implications for Fish Larvae Survival}

[53] As mentioned in the introduction, the objective of simulating the spatiotemporal distribution of primary and secondary productions is to represent the three-dimensional food environment of small pelagic fish of the southern Benguela. Both biogeochemical models NPZD and $\mathrm{N}_{2} \mathrm{P}_{2} \mathrm{Z}_{2} \mathrm{D}_{2}$ coupled to the ROMS hydrodynamical model simulate in a relatively realistic way the spatiotemporal distribution of chlorophyll $a$ in the southern Benguela upwelling ecosystem.

[54] On the Agulhas Bank, the spawning ground of sardines and anchovies, SC and DC models give a vertical structure in agreement with observations, both for the winter season, when the water column is well homogenized, and for the summer season, when stratification induces a subsurface chlorophyll maximum around $40 \mathrm{~m}$ depth, but also for spring, similar to summer. However, both biogeochemical models underestimate chlorophyll $a$ concentration levels in comparison with SeaWiFS measurements, the DC model being in closer agreement in terms of concentration levels as well as horizontal patterns. Blanke et al. [2002b] showed that weekly wind forcing induces higher SST variability. The typical upwelling event timescale is around 6 days [Nelson, 1992]; therefore the smoothing induced by the monthly wind forcing used in this study might be too drastic to reproduce nutrient input pulses driven by upwelling events.

[55] Zooplankton biomass is also better reproduced by the DC model. The differences between both models could come from the fact that copepods do not have the same prey abundance. In the SC model, zooplankton grazes upon one prey (phytoplankton), while in the DC model the large zooplankton (copepods shown here) may graze upon different prey types (flagellates, diatoms, and ciliates) with different capture efficiency. In terms of seasonal variability, biogeochemical models do reproduce favorable food conditions in spring-summer for fish larvae since both primary and secondary productions are higher than those in autumnwinter (Figures 9 and 10). The DC model offers even better food conditions to early life stages since the small zooplankton compartment peaks earlier and extends the period of high zooplankton biomass (Figure 11d).

[56] After hatching, larvae are rapidly advected away from the Agulhas Bank. Some get lost and die in the southern part of the south Atlantic subtropical gyre, some others reach the nursery ground along the west coast in St. Helena Bay and farther north [Hutchings et al., 1998; Plagányi et al., 2000]. Along the "sanitary corridor, i.e., from the western Agulhas Bank to the nursery ground (roughly north of Cape Columbine), the DC model provides a high food continuum on this pathway in agreement with observations, whereas the SC model presents a significant food discontinuity.

[57] Once in the nursery ground, primary and secondary productions provide optimal food environment for the development of fish larvae. Both models reproduce a highly productive west coast. Maxima of chlorophyll concentra- tions are encountered in the surface layers at the coast and they deepen offshore to generate a subsurface maximum within the subtropical gyre. At the surface, a strong inshore/ offshore gradient remains. The small phytoplankton compartment of the DC model produces a more diffuse gradient than the SC model. Concerning the zooplankton biomass, the DC model provides a certain advantage by simulating an observed double peak in spring and late summer (Figure 11). The time dynamics of peak occurrence is of crucial importance when upper trophic levels are to be linked with their food availability.

\section{Conclusions}

[58] The biogeochemical models NPZD and $\mathrm{N}_{2} \mathrm{P}_{2} \mathrm{Z}_{2} \mathrm{D}_{2}$ coupled to the ROMS hydrodynamical model simulate in a relatively realistic way the spatiotemporal distribution of chlorophyll $a$ and zooplankton in the southern Benguela upwelling ecosystem. The major features of this comparative study are summarized below.

[59] 1. Both models simulate high chlorophyll concentrations along the west coast in the active upwelling areas in agreement with SeaWiFS data, and relative lower concentrations over the Agulhas Bank. One major discrepancy between models results and observations is a poor depiction of the surface chlorophyll field over the Agulhas Bank. The inshore/offshore differences in chlorophyll concentrations are highly significant (i.e., strong inshore/offshore gradient) with a decrease from inshore to offshore. Nevertheless, chlorophyll concentration levels are lower than observed by the SeaWiFS sensor. A too low vertical resolution is pointed out to partly explain this behavior.

[60] 2. A strong seasonality in chlorophyll $a$ distributions with higher concentrations in summer and spring and lower concentrations in winter and autumn is well reproduced by both models.

[61] 3. Model simulations show that the primary production in the southern Benguela upwelling ecosystem is mainly dominated by new production in the intense upwelling areas with $\mathrm{f}$ ratios higher than 0.7 suggesting that these areas are large-cell (diatom-dominated) phytoplanktonic communities. The offshore areas, with $\mathrm{f}$ ratios lower than 0.4 (oligotrophic system), are dominated by regenerated production.

[62] 4. Modeled zooplankton biomass distributions reflect the overall patterns of chlorophyll with differences between the west coast and the Agulhas Bank, consistent with data, and these distributions exhibit a clear seasonal contrast. The DC model indicates that the seasonality of small and large zooplankton is quite distinct, which allows, from the Agulhas Bank to St. Helena Bay a spatiotemporal food continuum for fish larvae.

[63] It appears that both biogeochemical models (SC and DC) are able to simulate the overall spatiotemporal dynamics of the southern Benguela upwelling ecosystem with distinct functioning in the three main areas: the west coast very high productive area, the strongly stratified Agulhas Bank and the offshore oligotrophic area. The SC model seems less performant over the Agulhas Bank and in the oligotrophic areas. In these environments, smaller autotro- 
phic organisms such as flagellates are key players in the functioning of the ecosystem. The DC model provides more realistic results by considering major features all linked to the functioning of these regions (remineralization of detritus into ammonium which supports the regenerated production, smaller variety of prey sources for zooplankton, etc.).

\section{Appendix A: DC Model Sources-Minus-Sink Equations for State Variable}

[64]

$$
\begin{aligned}
\operatorname{sms}\left(N O_{3}\right)= & -\mu_{p_{s}}\left(N O_{3}\right)\left[P_{s}\right]-\mu_{p_{l}}\left(N O_{3}\right)\left[P_{l}\right]+\mu_{A N}\left[N H_{4}\right], \quad(\mathrm{A} 1) \\
\operatorname{sms}\left(N H_{4}\right)= & -\mu_{p_{s}}\left(N H_{4}\right)\left[P_{s}\right]-\mu_{p_{l}}\left(N H_{4}\right)\left[P_{l}\right]+\mu_{Z_{s A}}\left[Z_{s}\right]+\mu_{Z_{l A}}\left[Z_{l}\right] \\
& +\mu_{D_{s A}}\left[D_{s}\right]+\mu_{D_{l A}}\left[D_{l}\right]-\mu_{A N}\left[N H_{4}\right],
\end{aligned}
$$

$$
\begin{aligned}
\operatorname{sms}\left(P_{s}\right)= & \mu_{p_{s}}(N)\left[P_{s}\right]-g_{\max _{s}} \frac{e_{z_{s} p_{s}}\left[P_{s}\right]\left[Z_{s}\right]}{k_{z s}+e_{z_{s} p_{s}}\left[P_{s}\right]+e_{z_{s} p_{l}}\left[P_{l}\right]} \\
& -g_{\max _{l}} \frac{e_{z_{l} p_{s}}\left[P_{s}\right]\left[Z_{l}\right]}{k_{z l}+e_{z_{l} p_{s}}\left[P_{s}\right]+e_{z_{l} p_{l}}\left[P_{l}\right]+e_{z_{l} z_{s}}\left[Z_{s}\right]}-m_{P_{s D}}\left[P_{s}\right]
\end{aligned}
$$

$$
\begin{aligned}
\operatorname{sms}\left(P_{l}\right)= & \mu_{p_{l}}(N)\left[P_{l}\right]-g_{\max _{l}} \frac{e_{z_{l} p_{l}}\left[P_{l}\right]\left[Z_{l}\right]}{k_{z l}+e_{z_{l} p_{s}}\left[P_{s}\right]+e_{z_{l} p_{l}}\left[P_{l}\right]+e_{z_{l} z_{s}}\left[Z_{s}\right]} \\
& -g_{\text {max }_{s}} \frac{e_{z_{s} p_{l}}\left[P_{l}\right]\left[Z_{s}\right]}{k_{z s}+e_{z_{s} p_{s}}\left[P_{s}\right]+e_{z_{s} p_{l}}\left[P_{l}\right]}-m_{P_{l D}}\left[P_{l}\right]+L_{v s},
\end{aligned}
$$

$$
\begin{aligned}
\operatorname{sms}\left(Z_{s}\right)= & \beta_{s} \cdot g_{\max _{s}} \frac{\left(e_{z_{s} p_{s}}\left[P_{s}\right]+e_{z_{s} p_{l}}\left[P_{l}\right]\right)\left[Z_{s}\right]}{k_{z s}+e_{z_{s} p_{s}}\left[P_{s}\right]+e_{z_{s} p_{l}}\left[P_{l}\right]} \\
& -g_{\max _{l}} \frac{e_{z_{l} z_{s}}\left[Z_{s}\right]\left[Z_{l}\right]}{k_{z l}+e_{z l p_{s}}\left[P_{s}\right]+e_{z_{l} p_{l}}\left[P_{l}\right]+e_{z_{l} z_{s}}\left[Z_{s}\right]}-m_{Z_{s D}}\left[Z_{S}\right] \\
& -\mu_{Z_{s A}}\left[Z_{s}\right]
\end{aligned}
$$

$$
\begin{aligned}
\operatorname{sms}\left(Z_{l}\right)= & \beta_{l} \cdot g_{\max _{l}} \frac{e_{z_{l} p_{s}}\left[P_{s}\right]+e_{z_{l} p_{l}}\left[P_{l}\right]+e_{z_{l} z_{s}}\left[Z_{s}\right]}{k_{z l}+e_{z_{l} p_{s}}\left[P_{s}\right]+e_{z_{l} p_{l}}\left[P_{l}\right]+e_{z_{l} z_{s}}\left[Z_{s}\right]}\left[Z_{l}\right] \\
& -m_{Z_{l D}}\left[Z_{l}\right]-\mu_{Z_{l A}}\left[Z_{l}\right]
\end{aligned}
$$

$$
\begin{aligned}
\operatorname{sms}\left(D_{s}\right)= & \left(1-\beta_{s}\right) g_{\max _{s}} \frac{e_{z_{s} p_{s}}\left[P_{s}\right]+e_{z_{s} p_{l}}\left[P_{l}\right]}{k_{z s}+e_{z_{s} p_{s}}\left[P_{s}\right]+e_{z_{s} p_{l}}\left[P_{l}\right]}\left[Z_{s}\right]+m_{P_{s D}}\left[P_{s}\right] \\
& +m_{P_{l D}}\left[P_{l}\right]+m_{Z_{s D}}\left[Z_{S}\right]-\mu_{D_{s A}}\left[D_{s}\right]+L_{v s},
\end{aligned}
$$

$$
\begin{aligned}
\operatorname{sms}\left(D_{l}\right)= & \left(1-\beta_{l}\right) g_{\max _{l}} \frac{e_{z_{l} p_{s}}\left[P_{s}\right]+e_{z_{l} p_{l}}\left[P_{l}\right]+e_{z_{l z_{s}}}\left[Z_{s}\right]}{k_{z l}+e_{z_{l} p_{s}}\left[P_{s}\right]+e_{z_{l} p_{l}}\left[P_{l}\right]+e_{z_{l_{s}}}\left[Z_{s}\right]}\left[Z_{l}\right] \\
& +m_{Z_{l D}}\left[Z_{l}\right]-\mu_{D_{l A}}\left[D_{l}\right]+L_{v s} .
\end{aligned}
$$

[65] Acknowledgments. Support for this work was provided by a grant from IRD and is a contribution to the joint South African-French Programm ECO-UP. Ocean color data used in this study were produced by the SeaWiFS Project at Goddard Space Flight Center. Data were obtained from the Goddard Active Archive Center under the auspices of the National Aeronautics and Space Administration. The authors would like to specially thank the Department of Oceanography (F. Shillington), University of Cape Town. Zooplankton archived data were kindly provided by L. Drapeau. This work benefited from constructive discussion with B. Mitchell-Innes, J. Huggett, C. Moloney, and J. Field.

\section{References}

Andersen, V., and F. Rassoulzadegan (1991), Modèle vertical de l'écosystème pélagique marin, réseau microbien et sédimentation des particules biogéochimiques, J. Rech. Océanogr., 16(1, 2), 16-22.

Andrews, W. R. H., and L. Hutchings (1980), Upwelling in the southern Benguela current, Prog. Oceanogr., 9, 1-81

Bahamón, N., and A. Cruzado (2003), Modelling nitrogen fluxes in oligotrophic environments: NW Mediterranean and NE Atlantic, Ecol. Modell., 163, 223-244.

Bakun, A. (1996), Patterns in the Ocean Processes and Marine Population Dynamics, 323 pp., Univ. of Calif. Sea Grant, San Diego, Calif.

Barange, M., I. Hampton, and B. A. Roel (1999), Trends in the abundance and distribution of anchovy and sardine on the South African continental shelf in the 1990s, deduced from acoustic surveys, S. Afr. J. Mar. Sci., 21, 367-391.

Batchelder, H. P., C. A. Edwards, and T. M. Powell (2002), Individualbased models of copepod populations in coastal upwelling regions: Implications of physiologically and environmentally influenced die vertical migration on demographic success and nearshore retention, Prog. Oceanogr., 53, 307-333.

Biastoch, A., and W. Krauß (1999), The role of mesoscale eddies in the source regions of the Agulhas Current, J. Phys. Oceanogr., 29, $2303-$ 2317.

Blanke, B., C. Roy, P. Penven, S. Speich, J. McWilliams, and G. Nelson (2002a), Assessing wind contribution to the southern Benguela interannual dynamics, GLOBEC Int. Newsl., (8), 15-18.

Blanke, B., C. Roy, P. Penven, S. Speich, J. McWilliams, and G. Nelson (2002b), Linking wind and interannual upwelling variability in a regional model of the southern Benguela, Geophys. Res. Lett., 29(24), 2188, doi:10.1029/2002GL015718

Booth, B. C., and W. O. Smith Jr. (1997), Autotrophic flagellates and diatoms in the Northeast Water Polynya, Greenland: Summer 1993 J. Mar. Syst., 10, 241-261.

Brown, P. C. (1992), Spatial and seasonal variation in chlorophyll distribution in the upper $30 \mathrm{~m}$ of the photic zone in the southern Benguela/ Agulhas ecosystem, S. Afr. J. Mar. Sci., 12, 515-525.

Carr, M.-E. (2002), Estimation of potential productivity in Eastern Boundary Currents using remote sensing, Deep Sea Res., Part II, $49,59-80$

Chifflet, M., V. Andersen, L. Prieur, and I. Dekeyser (2001), Onedimensional model of short-term dynamics of the pelagic ecosystem in the NW Mediterranean Sea: Effects of wind events, J. Mar. Syst., 30, $89-$ 114.

Colella, P., and P. R. Woodward (1984), The piecewise parabolic method (PPM) for gas-dynamical simulations, J. Comput. Phys. 54, 174-201.

Conkright, M. E., S. Levitus, and T. P. Boyer (1994), World Ocean Atlas 1994, vol. 1, Nutrients, NOAA Atlas NESDIS 1, 162 pp., Natl. Oceanic and Atmos. Admin., Silver Spring, Md.

Da Silva, A. M., C. C. Young, and S. Levitus (1994), Atlas of Surface Marine Data 1994, vol. 1, Algorithms and Procedures, NOAA Atlas NESDIS 6, 74 pp., Natl. Oceanic and Atmos. Admin., Silver Spring, Md.

Demarcq, H., R. Barlow, and F. A. Shillington (2003), Climatology and variability of sea surface temperature and surface chlorophyll in the Benguela and Agulhas ecosystems as observed by satellite imagery, S. Afr. J. Mar. Sci., 25, 363-372.

Doney, S. C., D. M. Glover, and R. G. Najjar (1996), A new coupled, onedimensional biological-physical model for the upper ocean: Applications to the JGOFS Bermuda Atlantic Time-series Study (BATS) site, Deep Sea Res., Part II, 43, 591-624.

Dugdale, R. C., and J. J. Goering (1967), Uptake of new and regenerated forms of nitrogen in primary productivity, Limnol. Oceanogr., 12, 196206.

Fasham, M. J. R., H. W. Ducklow, and S. M. McKelvie (1990), A nitrogenbased model of plankton dynamics in the oceanic mixed layer, J. Mar Res., 48, 591-639. 
Fasham, M. J. R., P. W. Boyd, and G. Savidge (1999), Modeling the relative contribution of autotrophs and heterotrophs to carbon flow at a Lagrangian JGOFS station in the northeast Atlantic: The importance of DOC, Limnol. Oceanogr., 44, 80-90.

Flather, R. A. (1976), A tidal model of the northwest European continental shelf, Mem. Soc. R. Sci. Liège, 10, 141-164.

Gibbons, M. J., M. Barange, and S. C. Pillar (1991), Vertical migration and feeding of Euphausia lucens in the southern Benguela, J. Plankton Res., $13,473-486$

Glibert, P. M., J. C. Goldman, and E. J. Carpenter (1982), Seasonal variations in the utilization of ammonium and nitrate by phytoplankton in the Vineyard Sound, Massachusetts, USA, Mar. Biol., 70, $237-249$.

Huggett, J., P. Fréon, C. Mullon, and P. Penven (2003), Modelling the transport success of anchovy Engraulis encrasicolus eggs and larvae in the southern Benguela: The effect of spatio-temporal spawning patterns, Mar. Ecol. Prog. Ser., 250, 247-262.

Hurtt, G. C., and R. A. Armstrong (1996), A pelagic ecosystem model calibrated with BATS data, Deep Sea Res., Part II, 43, $653-683$.

Hutchings, L., G. C. Pitcher, T. A. Probyn, and G. W. Bailey (1995), The chemical and biological consequence of coastal upwelling, in Upwelling in the Oceans: Modern Processes and Ancient Records, edited by C. P. Summerhayes et al., pp. 65-81, John Wiley, Hoboken, N. J.

Hutchings, L., et al. (1998), Multiple factors affecting South African anchovy recruitment in the spawning, transport and nursery areas, S. Afr. J. Mar. Sci., 19, 211-225.

Lacroix, G., and P. Nival (1998), Influence of meteorological variability on primary production dynamics in the Ligurian Sea (NW Mediterranean Sea) with a 1D hydrodynamic/biological model, J. Mar. Syst., 16, $23-50$.

Liu, K.-K., S.-Y. Chao, P.-T. Shaw, G.-C. Gong, C.-C. Chen, and T. Y. Tang (2002), Monsoon-forced chlorophyll distribution and primary production in the South China Sea: Observations and a numerical study, Deep Sea Res., Part I, 49, 1387-1412.

Lutjeharms, J. R. E., P. Penven, and C. Roy (2003), Modelling the shear edge eddies of the southern Agulhas Current, Cont. Shelf Res., 23, 10991115 .

Marchesiello, P., J. C. McWilliams, and A. Shchepetkin (2001), Open boundary condition for long-term integration of regional oceanic models, Ocean Modell., 3, 1-20.

Marchesiello, P., J. C. McWilliams, and A. Shchepetkin (2003), Equilibrium structure and dynamics of the California Current System, J. Phys. Oceanogr., 33, 753-783.

McMurray, H. F., R. A. Carter, and M. I. Lucas (1993), Size-fractionated phytoplankton production in western Agulhas Bank continental shelf water, Cont. Shelf Res., 13, 307-329.

Mitchell-Innes, B. A., G. C. Pitcher, and T. A. Probyn (2000), Productivity of dinoflagellate blooms on the west coast of South Africa, as measured by natural fluorescence, S. Afr. J. Mar. Sci, 22, 273-284.

Moloney, C. L., J. G. Field, and M. I. Lucas (1991), The size-based dynamics of plankton food webs: II. Simulations of three contrasting southern Benguela food webs, J. Plankton Res., 13(5), 10391092.

Mullon, C., P. Fréon, C. Parada, C. D. Van Der Lingen, and J. A. Huggett (2003), From particles to individuals: Modelling the early stages of anchovy in the southern Benguela, Fish. Oceangr., 12(4, 5), 396406.

Nelson, G. (1992), Equatorward wind and atmospheric pressure spectra as metrics for primary productivity in the Benguela system, $S$. Afr. J. Mar. Sci., 12, 19-28.

Olivieri, R. A., and F. P. Chavez (2000), A model of plankton dynamics for the coastal upwelling system of Monterey Bay, California, Deep Sea Res., Part II, 47, 1077-1106.

Oschlies, A., and V. Garçon (1999), An eddy-permitting coupled physicalbiological model of the North Atlantic: 1. Sensitivity to advection numerics and mixed layer physics, Global Biogeochem. Cycles, 13(1), $135-160$.

Painting, S. J., M. I. Lucas, W. T. Peterson, P. C. Brown, L. Hutchings, and B. A. Mitchell-Innes (1993), Dynamics of bacterioplankton, phytoplankton and mesozooplankton communities during the development of an upwelling plume in the southern Benguela, Mar. Ecol. Prog. Ser., 100, $35-53$.

Parada, C., C. D. Van Der Ligen, C. Mullon, and P. Penven (2003), The effect of buoyancy on the transport of anchovy (Engrauls capensis) eggs from spawning to nursery grounds in the southern Benguela: An IBM approach, Fish. Oceanogr., 12, 1-15.
Parker, R. A. (1993), Dynamics models for ammonium inhibition of nitrate uptake by phytoplankton, Ecol. Modell., 66, 113-120.

Penven, P. (2000), A numerical study of the southern Benguela circulation with an application to fish recruitment, 2000, Ph.D. thesis, 160 pp., Univ. de Bretagne Occidentale, Brest, France. (Available at http:// www.brest.ird.fr/personnel/ppenven/publications/these/index.html)

Penven, P., J. R. E. Lutjeharms, P. Marchesiello, C. Roy, and S. J. Weeks (2001a), Generation of cyclonic eddies by the Agulhas Current in the lee of the Agulhas Bank, Geophys. Res. Lett., (28), 1055-1058.

Penven, P., C. Roy, J. R. E. Lutjeharms, A. Colin de Verdire, A. Johnson, F. Shillington, P. Fréon, and G. Brundrit (2001b), A regional hydrodynamic model of the southern Benguela, S. Afr. J. Sci., (97), 472476.

Peterson, W. T., S. J. Painting, and L. Hutchings (1990), Diel variations in gut pigment content, diel vertical migration and estimates of grazing impact for copepods in the southern Benguela upwelling region in October 1987, J. Plankton Res., 12(2), 259-281.

Pitcher, G. C., and A. J. Boyd (1996), Cross-shelf and along-shore dinoflagellate distributions and the mechanisms of red tide formation within the southern Benguela upwelling system, in Harmful and Toxic Algal Blooms, edited by T. Yasumoto, Y. Oshima, and Y. Fukuyo, pp. $243-$ 246, Intergov. Oceanogr. Comm. of UNESCO, Paris.

Plagányi, E. E., L. Hutchings, and J. G. Field (2000), Anchovy foraging: Simulating spatial and temporal match/mismatches with zooplankton, Can. J. Fish. Aquat. Sci., 57, 2044-2053.

Popova, E. E., C. J. Lozano, M. A. Srokosz, M. J. R. Fasham, P. J. Haley, and A. R. Robinson (2002), Coupled 3D physical and biological modelling of the mesoscale variability observed in north-east Atlantic in spring 1997: Biological processes, Deep Sea Res., Part I, 49, $1741-1768$

Probyn, T. A. (1987), Ammonium regeneration by microplankton in an upwelling environment, Mar. Ecol. Prog. Ser., 37, 53-64.

Probyn, T. A. (1992), The inorganic nitrogen of phytoplankton in the southern Benguela: New production, phytoplankton size and implications for pelagic foodwebs, S. Afr. J. Mar. Sci., 12, 411-420.

Radach, G., and A. Moll (1993), Estimation of the variability of production by simulating annual cycles of phytoplankton in the central North Sea, Prog. Oceanogr., 31, 339-419.

Raymond, W. H., and H. L. Kuo (1984), A radiation boundary condition for multi-dimensional flows, Q. J. R. Meteorol. Soc., 110, 535-551.

Shannon, L. V., and J. G. Field (1985), Are fish stocks food-limited in the southern Benguela pelagic ecosystem?, Mar. Ecol. Prog. Ser., 22, $7-19$.

Shannon, L. V., and G. Nelson (1996), The Benguela: Large scale features and processes and system variability, in The South Atlantic: Past and Present Circulation, edited by G. Wefer et al., pp. 163-210, Springer, New York.

Shannon, L. V., and M. J. O'Toole (1999), Integrated overview of the oceanography and environmental variability of the Benguela current region: Synthesis and assessment of information on the Benguela curren large marine ecosystem (BCLME), Them. Rep. 2, Benguela Current Large Mar. Ecosyst. Project, Windhoek, Namibia.

Shannon, L. V., L. Hutchings, G. W. Bailey, and P. A. Shelton (1984) Spatial and temporal distribution of chlorophyll in Southern African waters as deduced from ship and satellite measurements and their implications for pelagic fisheries, S. Afr. J. Mar. Sci., 2, 109-130.

Shchepetkin, A. F., and J. C. McWilliams (2003), A method for computing horizontal pressure-gradient force in an ocean model with a non-aligned vertical coordinate, J. Geophys. Res., 108(C3), 3090, doi:10.1029/ 2001JC001047.

Shchepetkin, A. F., and J. C. McWilliams (2005), The Regional Ocean Model System (ROMS): A split-explicit, free-surface, topographyfollowing-coordinate oceanic model, Ocean Modell., 9, 347-404.

Shillington, F. P. (1998), The Benguela upwelling system off Southwestern Africa, coastal segment $\left(16^{\circ} \mathrm{E}\right)$, in The Sea II: The Global Coastal Ocean, edited by A. R. Robinson and K. H. Brink, pp. 583-604, John Wiley, Hoboken, N. J.

Takahashi, M., I. Koike, K. Iseki, P. K. Bienfang, and A. Hattori (1982), Phytoplankton species responses to nutrient changes in experimental enclosures and coastal waters, in Marine Mesocosms, Biological and Chemical Research in Experimental Ecosystems, edited by G. D. Grice and M. R. Reeve, pp. 332-340, Springer, New York.

Tian, R. C., et al. (2000), Effects of pelagic food-web interactions and nutrient remineralization on the biogeochemical cycling of carbon: A modeling approach, Deep Sea Res., Part II, 47, 637-662.

Tian, R. C., A. F. Vézina, M. Starr, and F. Saucier (2001), Seasonal dynamics of coastal ecosystems and export production at high latitudes: A modeling study, Limnol. Oceanogr., 46, 1845-1859. 
Touratier, F., J. G. Field, and C. L. Moloney (2003), Simulated carbon and nitrogen flows of the planktonic food web during an upwelling relaxation period in St. Helena Bay (southern Benguela ecosystem), Prog. Oceanogr., 58, 1-41.

Verheye, H. M. (1991), Short-term variability during an anchor station study in the southern Benguela upwelling system: Abundance, distribution and estimated production of mesozooplankton with special reference to Calanoides carinatus (Kroyer, 1849), Prog. Oceanogr., 28, 91-119.

Waldron, H. N., and T. A. Probyn (1992), Nitrate supply and potential new production in the Benguela upwelling system, S. Afr. J. Mar. Sci., 12, $29-39$.

Waldron, H. N., T. A. Probyn, and G. B. Brundrit (1997), Preliminary annual estimates of regional nitrate supply in the southern Benguela using coastal sea level fluctuations as a proxy for upwelling, S. Afr. J. Mar. Sci., 18, 93-105.

Ware, D. M. (1992), Production characteristics of upwelling systems and the trophodynamic role of hake, S. Afr. J. Mar. Sci., 12, 501-513.
Weijer, W., W. P. M. de Ruijter, H. A. Dijkstra, and P. J. van Leeuwen (1999), Impact of interbasin exchange and the Atlantic overturning circulation, J. Phys. Oceanogr., 29, 2266-2284.

V. Andersen, Laboratoire d'Océanographie de Villefranche, Observatoire Océanologique, CNRS-Université Paris VI, BP 28, F-06234 Villefranchesur-mer, France.

H. Demarcq, P. Fréon, V. Koné, and E. Machu, Centre de Recherche Halieutique Méditerranéenne et Tropicale, Rue Jean Monnet, B.P. 171, F-34203 Sète, France. (vkone@ifremer.fr)

V. Garçon, Laboratoire d'Etudes en Géophysique et Océanographie Spatiales CNRS, 18 avenue E. Belin, F-31401 Toulouse, France.

P. Penven, Department of Oceanography, University of Cape Town, R.W. James Building, Private Bag 7701 Rondebosch, South Africa. 